\title{
Izjašnjavanje sandžačkih Bošnjaka o nacionalnoj pripadnosti u popisima stanovništva (1948. - 2011.)
}

DOI: $10.11567 /$ met.34.1.1 UDK: 342.814:351.755.3[(497.11Sandžak=163.4)"1948/2011"

Pregledni rad

Primljeno: 27.06.2018. Prihvaćeno: 28.09.2018.

\section{Saša Mrduljaš}

Institut društvenih znanosti Ivo Pilar - Područni centar Split, Split sasa.mrduljas@pilar.hr

\begin{abstract}
SAŽETAK
Unatoč tome što je bošnjačka zajednica u Sandžaku integralni dio bošnjačke nacije, po nizu značajki predstavlja njezin posebni segment. U kontekstu te posebnosti pokušalo se utvrditi u kojoj je mjeri popisno iskazivanje njezinih pripadnika o etničkoj ili nacionalnoj pripadnosti bilo sukladno izjašnjavanju Bošnjaka u Bosni i Hercegovini, kako na razini ukupnog Sandžaka tako i njegova srpskog te crnogorskog dijela. Ujedno, analizom je omogućena i usporedba Bošnjaka u navedena dva dijela Sandžaka. Predmet istraživanja ponajprije su bili rezultati popisa provedenih između 1948. i 2011. s obzirom na to da pružaju uvid u takav tip očitovanja kod svih etničkih skupina, pa tako i bošnjačke. Mada popisi iz 1948., 1953. i 1961. upravo u slučaju Bošnjaka nisu bili usklađeni s realnošću njihove samosvojnosti, ipak su im nudili određenu mogućnost da je iskažu. To su Bošnjaci Bosne i Hercegovine velikom većinom i činili. U Sandžaku je bilo bitno drugačije, s tim da su postojale očite razlike između njegova dva dijela. Do ujednačivanja dolazi nakon što je krajem šezdesetih politički prihvaćena konstitucija nacije »Muslimana«. U popisima iz 1971., 1981. i 1991. Bošnjaci Bosne i Hercegovine i Sandžaka gotovo se u potpunosti identificiraju kao pripadnici te narodne cjeline. Određene razlike nanovo se pojavljuju nakon što je u bošnjačkom korpusu početkom devedesetih prihvaćeno bošnjačko ime kao nacionalno. Popisi koji su slijedili u Srbiji i Crnoj Gori (2002./03. i 2011.) pokazali su da se znatni dio Sandžaklija i nadalje doživljava Muslimanima. Nasuprot tome, popis koji je 2013. proveden u Bosni i Hercegovini očitovao je da je u toj zemlji bošnjačko ime gotovo u potpunosti prevladalo među nekadašnjim Muslimanima.
\end{abstract}

KLJUČNE RIJEČI: Sandžak, Bosna i Hercegovina, Bošnjaci, Srbi, Crnogorci, popisi stanovništva 


\section{UVOD}

Mada je bošnjačka zajednica u Sandžaku integralni dio bošnjačke nacije, po svom geografskom položaju, povijesnom razvoju i političkim prilikama s kojima se suočavala ili suočava predstavlja njezin posebni ogranak. Ta se posebnost ogleda i u tome da je prvi suvremeni popis stanovništva $\mathrm{BiH}$, a time i tamošnjih Bošnjaka, proveden 1879., a na Sandžaku, sukladno okolnostima u kojima je bio, tek četrdesetak godina poslije, tj. 1921. U ovom radu bit će prezentirani podaci koji pružaju uvid u etničke značajke Sandžaka kako za navedeni popis tako i za sve naredne zaključno s posljednjim iz 2011., dakle podaci popisa koji su se proveli u više država, odnosno u Kraljevini Srba, Hrvata i Slovenaca (SHS) (od 1929. Kraljevini Jugoslaviji), Socijalističkoj Jugoslaviji, Saveznoj Republici Jugoslaviji/Državnoj zajednici Srbije i Crne Gore (1992. - 2003./2003. - 2006.) te u samostalnoj Srbiji i Crnoj Gori (od 2006.).

Pokazatelji koji će biti predočeni odnose se na ukupnu populaciju Sandžaka te su uvidom u njih moguće raznovrsne analize, usporedbe i zaključci - od analiza koje bi polazile od razmatranja cjeline sandžačkog stanovništva, pojedinih etničkih skupina unutar njega i njihovih brojčanih suodnosa pa sve do onih koje bi se zadržavale na razini pojedinačnih upravno-teritorijalnih jedinica. Kako smo u svome radu fokusirani na bošnjačku zajednicu, ovdje ćemo se zadržati na jednom sasvim određenom istraživačkom cilju. Naime pokušat ćemo utvrditi u kojoj je mjeri popisno iskazivanje njenih pripadnika o etničkoj ili nacionalnoj pripadnosti bilo sukladno izjašnjavanju Bošnjaka u BiH, kako na razini ukupnog Sandžaka tako i njegova srpskog i crnogorskog dijela. Istovremeno će nam analiza omogućiti i usporedbu popisnog izjašnjavanja Bošnjaka u navedena dva dijela Sandžaka.

U vezi s iznesenim ciljem, prva dva popisa, onaj iz 1921. te sljedeći iz 1931., praktično su neupotrebljiva jer nisu registrirala etničku pripadnost. U njima su iskazani podaci o vjeri i materinjem jeziku te se do podataka o etničkoj pripadnosti može doći samo posredno, tj. kombinacijom tih dvaju pokazatelja. Valja imati na umu da tako dobiveni podaci, koji imaju tek približnu vrijednost, ne znače da bi se i popisano stanovništvo, da je tih godina imalo priliku izjašnjavanja o svojoj etničkoj pripadnosti, tako i izjasnilo. No riječ je o popisima koji imaju referentnu važnost za naredna razdoblja te stoga ovdje prilažemo i njihove pokazatelje.

Predmet naše analize prije svega će biti rezultati popisa koji su provedeni od 1948. do 2011., oni koji omogućuju uvid u etničko ili nacionalno pozicioniranje svih etničkih skupina, pa tako i bošnjačke. Mada popisi iz 1948., 1953. i 1961., sukladno političkim prilikama, upravo u slučaju Boš- 
njaka nisu bili usklađeni s realnošću njihove samosvojnosti, ipak su nudili mogućnosti preko kojih su i oni mogli, iako neizravno, iskazati vlastitu samobitnost. Od 1971., u uvjetima političkog priznanja nacionalne posebnosti Bošnjaka, tada kao »Muslimana«, nastaju kvalitativno nove okolnosti, koje se iskazuju i prilikom popisa. One se donekle mijenjaju po zamjeni muslimanskog nacionalnog imena bošnjačkim početkom devedesetih, o čemu svjedoče i rezultati popisa kojima je Sandžak obuhvaćen nakon raspada Socijalističke Jugoslavije.

\section{OBLIKOVANJE MUSLIMANSKE/BOŠNJAČKE NACIJE}

U jezičnom smislu južnoslavenski prostor podijeljen je na zapadnu i istočnu cjelinu. Zapadnoj pripadaju Slovenci, Hrvati, Bošnjaci, Srbi i Crnogorci, a istočnoj Bugari i Makedonci. Zapadna južnoslavenska formacija dijeli se pak na dvije podcjeline: jednoj pripadaju slovenski govori, a drugoj govori Hrvata, Bošnjaka, Srba i Crnogoraca. Ta druga podcjelina, budući da se nalazi između slovenske i bugarsko-makedonske zone, naziva se »središnjim južnoslavenskim jezičnim dijasistemom «, unutar kojeg su i najudaljeniji govori međusobno razumljivi (v. Brozović, 1997: 127; Brozović i Ivić, 1988: 1-5; Jahić, 1991: 9-15; Lisac, 1996: 9-21).

Jezična, uvjetno rečeno, istovrsnost značajno je utjecala na nacionalnoformativne napore koji u hrvatskoj i srpskoj sredini počinju u prvoj polovini 19. stoljeća. U svojem početnom obliku oni su težili da pod jednim imenom i unutar jedne nacije okupe cjelinu ili veći dio slavenske populacije navedenog prostora, i to unatoč različitosti njezina političko-povijesnog razvoja $\mathrm{i}$ iskustva te vjerskoj heterogenosti očitovanoj u pripadnosti katolicizmu, pravoslavlju i islamu. No vrlo se brzo pokazalo da se ovdašnje katolike i pravoslavce ne može unificirati putem transkonfesionalnih nacionalno-idejnih konstrukcija. Umjesto toga, približno do kraja 19. stoljeća okončava se identifikacija katoličkog življa s nacionalnim hrvatstvom te pravoslavnog, uz posebnost crnogorskog »slučaja«, sa srpstvom (v. Banac, 1988: 75-116).

Do tada još uvijek nije bilo jasno što bi u nacionalnom smislu trebali biti ovdašnji muslimani (dalje: Bošnjaci). U vremenu otpočinjanja nacionalnoformativnih procesa oni su bili dijelom Osmanskog Carstva, tj. islamskoteokratske države na čelu sa sultanom, ujedno i kalifom ili predvodnikom sunitskih muslimana (Matuz, 1992: 56-64). S tim su se Carstvom poistovjećivali, bili mu odani te time ostali izvan procesa koji su vodili oblikovanju nacija. Taj tip odanosti zadržao se kod bosanskohercegovačkih Bošnjaka i nakon što je tu zemlju 1878. zauzela Austro-Ugarska, zbog toga što je BiH nominalno ostala 
pod Osmanskim Carstvom te što je ono već u susjednom Sandžaku, pretežito nastanjenom Bošnjacima, zadržalo svoje pozicije.

U tim uvjetima pokušaji Austro-Ugarske da kod stanovništva BiH ukorijeni ideju nacionalnog bošnjaštva nisu davali rezultate ne samo među katolicima i pravoslavcima, koji se identificiraju s hrvatstvom odnosno srpstvom, već ni među samim muslimanima (Kraljačić, 1987: 276). Tako su praktično sve njihove organizacije $\mathrm{u}$ svom nazivu nosile samo vjerski, tj. muslimanski naziv (Filandra, 1998: 16). Promjene će nastupiti nakon što 1908. AustroUgarska anektira BiH te poslije balkanskih ratova 1912. - 1913., za kojih je Osmansko Carstvo izgubilo gotovo sve europske posjede.

Identifikacija s tim Carstvom više nije imala političkog smisla, te su se Bošnjaci jednostavno morali okrenuti drugim mogućnostima. U njihovoj sredini već su bile duboko ukorijenjene hrvatska i srpska nacionalna ideja, koje su im bile prilagođene svojom transkonfesionalnom širinom. Na Bošnjake su gledale kao na islamizirane Hrvate tj. Srbe te priželjkivale njihovu inkorporaciju $\mathrm{u}$ vlastite nacionalne okvire. Tako se krajem austrougarske vlasti, $\mathrm{u}$ vremenu do kojeg nisu izgradili vlastitu nacionalnu misao, kad čine tek tridesetak posto stanovništva $\mathrm{BiH}$, u kojem su stiješnjeni između brojnijih i državotvorno aktivnih Hrvata i Srba, Bošnjaci sve više otvaraju prema nacionalnim idejama tih naroda, posebice prema hrvatskoj (v. Hadžijahić, 1990: 220).

U Kraljevini Srba, Hrvata i Slovenaca/Jugoslaviji, što je vidljivo već iz njezina prvotnog naziva, nije se priznavala etnička posebnost kako Bošnjaka tako ni Crnogoraca te Makedonaca. Unatoč tome što su na hrvatskoj i srpskoj strani postojala različita očekivanja u odnosu na nacionalno opredjeljenje Bošnjaka, obostrano je prevladavalo uvjerenje da oni jedino mogu biti Hrvati ili Srbi. U tim okolnostima, kada gotovo moraju birati između hrvatstva i srpstva, nastavljala se, sada već u znatnijoj mjeri, inklinacija Bošnjaka nacionalnom hrvatstvu (Pribićević, 1990: 24).

Cijeli taj proces ipak se pretežito zadržavao na razini deklarativnosti, $i$ to unutar društvene elite bošnjačke zajednice. Vodeća stranka u njoj, Jugoslavenska muslimanska organizacija (JMO), primarno je težila očuvanju kohezije te ako je moguće i teritorijalnog jedinstva vlastitog naroda (Boban, 1965: 259-260, 316). Stoga je unutar bošnjačkoga korpusa izbjegavala unositi ili produbljivati dilemu vezanu uz nacionalno izjašnjavanje, pa i ono koje bi bilo afirmativno za bošnjačku nacionalnu samobitnost. Pitanje odabira nacionaliteta nije samo prijetilo rastvaranju unutrašnjeg jedinstva već je u ozračju međunacionalnih tenzija, kakvo je vladalo u Kraljevini, i izlagalo bošnjački korpus dodatnim konfrontacijama. Djelujući u tim prilikama, unatoč hrvatskim i u manjoj mjeri srpskim tendencijama među Bošnjacima, JMO 
je u osnovi vodio samosvojnu politiku, nerijetko suprotnu od onih koje su prevladavale među Hrvatima i Srbima (Purivatra, 1974). Time je i bez nekog formalnog isticanja bošnjačke posebnosti davao na znanje da uistinu predvodi zasebnu etničku formaciju.

Na prostorima bivše Jugoslavije Drugi svjetski rat okončan je pobjedom Narodno-oslobodilačkog pokreta pod vodstvom Komunističke partije Jugoslavije (KPJ). Time su omogućene dalekosežne promjene na nacionalnom polju, uz ostalo i preustrojem Jugoslavije u federaciju šest republika. U sklopu tog preustroja oblikovana je i Narodna (od 1963. Socijalistička) Republika BiH, koja je imala biti svojevrsnom tampon-zonom između Hrvatske i Srbije, takvom koja će pridonijeti trajnom otklanjanju konfliktne dimenzije hrvatsko-srpskih odnosa (Isaković, 1990: 300).

Osim toga KPJ je još u predratnom, a posebice u ratnom razdoblju uviđala posebnost položaja u kojem se nalazila bošnjačka zajednica kao i da »otimanje« za nju produbljuje hrvatsko-srpski jaz. Stoga je otvarala prostor afirmaciji bošnjačke posebnosti (Duraković, 1993: 165). No ni ona nije bila imuna na duboko ukorijenjene percepcije po kojima su Bošnjaci porijeklom Hrvati i Srbi te da je gotovo prirodno da to »iznova« budu (v. Kamberović, 2009: 59). Zbog tih je kontradikcija politika KPJ (od 1952. Saveza komunista Jugoslavije/SKJ) još dugo nakon rata bila dvoznačna u odnosu na rješenje »bošnjačkog pitanja«.

$S$ jedne strane prekinuta je propaganda usmjerena na »nacionaliziranje « Bošnjaka u hrvatskom ili srpskom smislu, dok s druge nije ometano njihovo izjašnjavanje kao Srba, Hrvata ili Crnogorca. Osim toga, dok je KPJ dala snažan poticaj etabliranju crnogorske i makedonske nacije, izbjegla je takvo što učiniti u bošnjačkom slučaju, s tim da je ostavljala određeni, pojmovno nedefinirani prostor iskazivanju bošnjačke etničke posebnosti, a time i distanciranju od nacionalnoga hrvatstva, srpstva te sada već i crnogorstva. Tako su se u prvom popisu stanovništva iz 1948. Bošnjaci mogli izjasniti kao »neopredijeljeni muslimani«, u idućem iz 1953. kao »Jugoslaveni-neopredijeljeni«, a u onom iz 1961. kao »Muslimani u smislu etničke pripadnosti«. Tek su tijekom druge polovine šezdesetih donesene političke odluke kojima je konačno prihvaćeno da je riječ o posebnoj naciji te joj je pritom određen naziv »Muslimani«(Kamberović, 2009: 61). Tako će se, tj. kao »Muslimani u smislu narodnosti«, na iduća tri jugoslavenska popisa, iz 1971., 1981. i 1991., odrediti golema većina Bošnjaka.

Političkim "potvrđivanjem « muslimanske nacije razriješeno je jedno dugo otvoreno pitanje iz sfere (među)nacionalnih statusa i odnosa. No riječ je bila o naciji kojoj je za ime određen vjerski naziv, što svakako nije bilo naj- 
sretnije rješenje. Napokon, po raspadu Jugoslavije i uspostavi neovisne BiH, na Drugome bošnjačkom saboru održanom krajem 1993. donesena je odluka da se nacionalni naziv »Muslimani« zamijeni tradicionalnim imenom »Bošnjaci«, što je gotovo unisono prihvaćeno u bošnjačkom korpusu (Imamović, 1998: 569).

\section{POJAM SANDŽAKA}

Gledišta o tome što je Sandžak, koje krajeve zauzima, nisu posve ujednačena. Stoga je nužno definirati što smatramo pod tim pojmom. U povijesnom smislu, za trajanja osmanske vlasti nad ovdašnjim prostorima, riječ je bila o najistočnijem dijelu Bosanskog pašaluka. Nakon što je Austro-Ugarska zauzela BiH, taj dio ostaje pod osmanskom vlašću, i to u sklopu Kosovskog vilajeta. U teritorijalnom smislu predstavljao je svojevrstan geopolitički klin između Srbije i Crne Gore. Za taj dio nekadašnje osmanske Bosne, budući da je povremeno predstavljao jedinstvenu upravnu cjelinu, ustalio se naziv Novopazarski sandžak. Unatoč tome tijekom završne faze osmanske vlasti bio je razdijeljen između Pljevljanskog, Sjeničkog, Pećkog i Prištinskog sandžaka (Kosančić, 1912: 1, 16-18). Cijeli taj kraj podijeljen je 1912., za Prvoga balkanskog rata, između Srbije i Crne Gore. Podjela je vrlo kratko trajala jer je počeo Prvi svjetski rat (1914. - 1918.) i te su dvije zemlje okupirane. Po njegovu je okončanju Crna Gora inkorporirana u sastav Srbije, koja potom postaje dijelom Kraljevine SHS/Jugoslavije (1918. - 1941.). Sandžak je iznova podijeljen nakon Drugoga svjetskog rata (1939. - 1945.) federalizacijom Socijalističke Jugoslavije. Tada je, približno po liniji iz 1912., njegov sjeverni dio postao dijelom Srbije, a južni Crne Gore.

U novim prilikama mijenja se i doživljaj prostornog okvira Sandžaka. Dijelom Novopazarskog sandžaka bila je i Mitrovica (Kosovska, Titova) sa svojom okolicom. Naknadno postaje dijelom Kosova te se na nju gleda s tog stajališta. S druge strane, suvremeni pojam Sandžaka uključuje područje Plava u Crnoj Gori, koje se prethodno u pravilu nije doživljavalo kao njegov dio. Mada Sandžak ostaje prepoznatljiv kao zasebna formacija, u osnovi je riječ o povijesnoj percepciji održavanoj posebnošću njegova etničkoga karaktera, dakle kao kraja u kojem obitavaju Bošnjaci (pretežito na istoku, prema Kosovu) te Srbi i Crnogorci (pretežito na zapadu, prema BiH).

Za trajanja Jugoslavije, što se nastavilo i poslije, ni srpski ni crnogorski dio Sandžaka nisu imali poseban političko-teritorijalni status. Bili su dijelom lokalnih upravnih jedinica, koje su s vremenom mijenjale svoj opseg. Te promjene nisu bile znatne, no bilo ih je, s tim da su se $u$ najuočljivijoj 
mjeri odvijale na razini andrijevičkoga kraja. Bez analize tih promjena te njihovih učinaka kako na vanjski okvir Sandžaka tako i na njegovu unutarnju podjelu ne može se usporediti sandžačke etničke suodnose u vremenima u kojima su se razlikovale njegove teritorijalno-upravne značajke. Usporedbe su moguće tek od 1961., kad stječe postojeći okvir. Od tada se njegov srpski dio sastoji od šest općina: Priboj, Nova Varoš, Prijepolje, Sjenica, Novi Pazar i Tutin, a crnogorski od pet: Pljevlja, Bijelo Polje, Ivangrad, Rožaj (od popisa 2003. »Rožaje«) i Plav (v. sliku 1), s tim da je 1990. od južnog dijela općine Ivangrad (iznova) oformljena općina Andrijevica, a od njenog nasjevernijeg dijela 2012. općina Petnjica. Pri navedenim i sličnim usporedbama valja međutim voditi računa o mogućoj različitosti metodologija koje su primijenjene prilikom provođenja popisa koji se uspoređuju (pitanje regulacije stalnoga, iseljenog i doseljenog stanovništva, radnika na privremenom radu u inozemstvu itd.).

Sukladno prikazanom okviru, Sandžak zauzima $8687 \mathrm{~km}^{2}$, pri čemu njegov srpski dio $4499 \mathrm{~km}^{2}$ (51,8\%) a crnogorski 4188 km² (48,2\%) (Bertić, 1987: $230,236)$. U radu će se istaknuti etnički suodnosi u Sandžaku prilikom analize svakog od popisa, primarno zbog uvida u stanje koje je njime registrirano, a manje zbog usporedbe rezultata različitih popisa. Kako predmet rada nije usporedba etnodemografskih relacija u samom Sandžaku, povijesne promjene njegova vanjskog okvira kao i granica između njegovih upravnih jedinica nisu važne za naše istraživanje. Neovisno o tim promjenama, putem svakog od popisa bilo je moguće doći do podataka koji su nam relevantni i omogućuju uvid u prilike u kontekstu ukupne bošnjačke zajednice unutar Sandžaka.

Osim promjena granica upravnih cjelina, u pojedinim slučajevima mijenjali su se i njihovi nazivi. Tako su u starijim razdobljima nazivi općina Prijepolje, Tutin i Novi Pazar bili Mileševa, Štavica i Deževa. Grad Berane, po kojemu su se nazivale sve cjeline kojima je povijesno bio središtem (okrug, srez i općina), između 1949. i 1992. nazivan je Ivangradom. Nadalje, u priloženim tablicama posebno će biti istaknute upravne jedinice srpskoga, a posebno crnogorskog dijela Sandžaka. Bit će navedene sukladno svome geografskom položaju na relaciji zapad - istok, s tim da će u konačnici biti predstavljeni rezultati za cjelinu promatranog prostora. U svim će tablicama osim govornika »srpsko-hrvatskog« (»Srbi ili Hrvati«) (Kraljevina SHS/Jugoslavija), tj. Bošnjaka, Srba i Crnogoraca (popisi od 1948.), biti obuhvaćeni i govornici albanskoga, odnosno Albanci, jer predstavljaju, uvjetno rečeno, autohtone stanovnike istočnog dijela Sandžaka. Što se tiče samog bošnjačkog naziva, on je unatoč svojoj povijesnosti, kako je već rečeno, tek krajem 1993. stekao ulogu nacionalnog imena bošnjačke zajednice. No kako bi se izbjegle 
nejasnoće, u pravilu se tim nazivom koristimo za označivanje bošnjačkog naroda u svim razmatranim razdobljima.

Slika 1. Općine Srbije i Crne Gore koje oblikuju prostor Sandžaka (1961. 1981.)

Figure 1. Municipalities of Serbia and Montenegro which shape Sandžak (1961-1981)

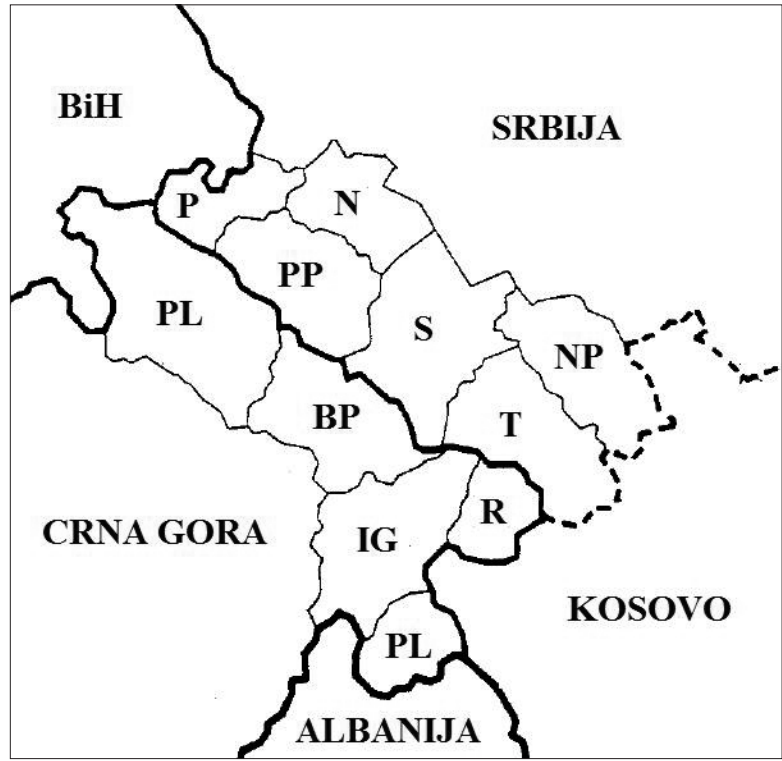

Legenda: Pune istaknute linije - republičke / državne granice; pune tanke linije - općinske granice (1961-1981); isprekidane linije - granica između Kosova i (ostatka) Srbije; sandžačke općine u Srbiji: P - Priboj, N - Nova Varoš, PP - Prijepolje, S - Sjenica, NP - Novi Pazar, T - Tutin; sandžačke općine u Crnoj Gori: PL - Pljevlja, BP - Bojelo Polje, IG - Ivangrad (Berane), R - Rožaje, PL - Plav.

Izvor: Kartu izradio autor prema predlošku u: Popis stanovništva i stanova 1971. Stanovništvo etnička, prosvetna i ekonomska obeležja stanovništva i domaćinstava prema broju članova (rezultati po opštinama), knjiga VI., priredili: Grabeljšek, D. i sur., SFRJ-Savezni zavod za statistiku, Beograd, 1994. 


\section{BOŠNJACI SANDŽAKA U POPISIMA KRALJEVINE SHS/ JUGOSLAVIJE}

\subsection{Popis iz 1921.}

U vrijeme provođenja popisa iz 1921. Sandžak je bio podijeljen na šest okruga. Pritom su se dva, Prijepolje i Raška, nalazila na tlu današnje Srbije. Na prostoru današnje Crne Gore nalazili su se okruzi Pljevlja, Bijelo Polje, Berane i Andrijevica. Svaki od njih, kao što se vidi iz tablice 1, sastojao se od više srezova te od općine koju je formiralo upravno središte samog okruga.

Kod popisa iz 1921. do podataka o etničkoj pripadnosti može se doći samo posredno, kombinacijom pokazatelja koji se odnose na vjeru i materinji jezik. Broj Srba/Crnogoraca dobiven je tako da smo od broja pravoslavaca oduzeli govornike ruskog i rumunjskog, a broj Bošnjaka tako da smo od broja muslimana oduzeli govornike turskog i albanskog, uz izuzetak približnog dijela katoličkih govornika albanskog (373) nastanjenih u srezu Plav-Gusinje. Sveukupno, 1921. od 216.120 stanovnika Sandžaka približno je 96.201 ili 44,5\% Bošnjaka, 115.653 ili 53,5\% Srba/Crnogoraca, 2989 ili 1,4\% Albanaca te 976 ili 0,5\% ostalih. S obzirom na naknadni razvoj važno je uočiti da je među »ostalima« Turaka bilo 551 te da su u brojčanom smislu predstavljali minorni dio sandžačke populacije. 


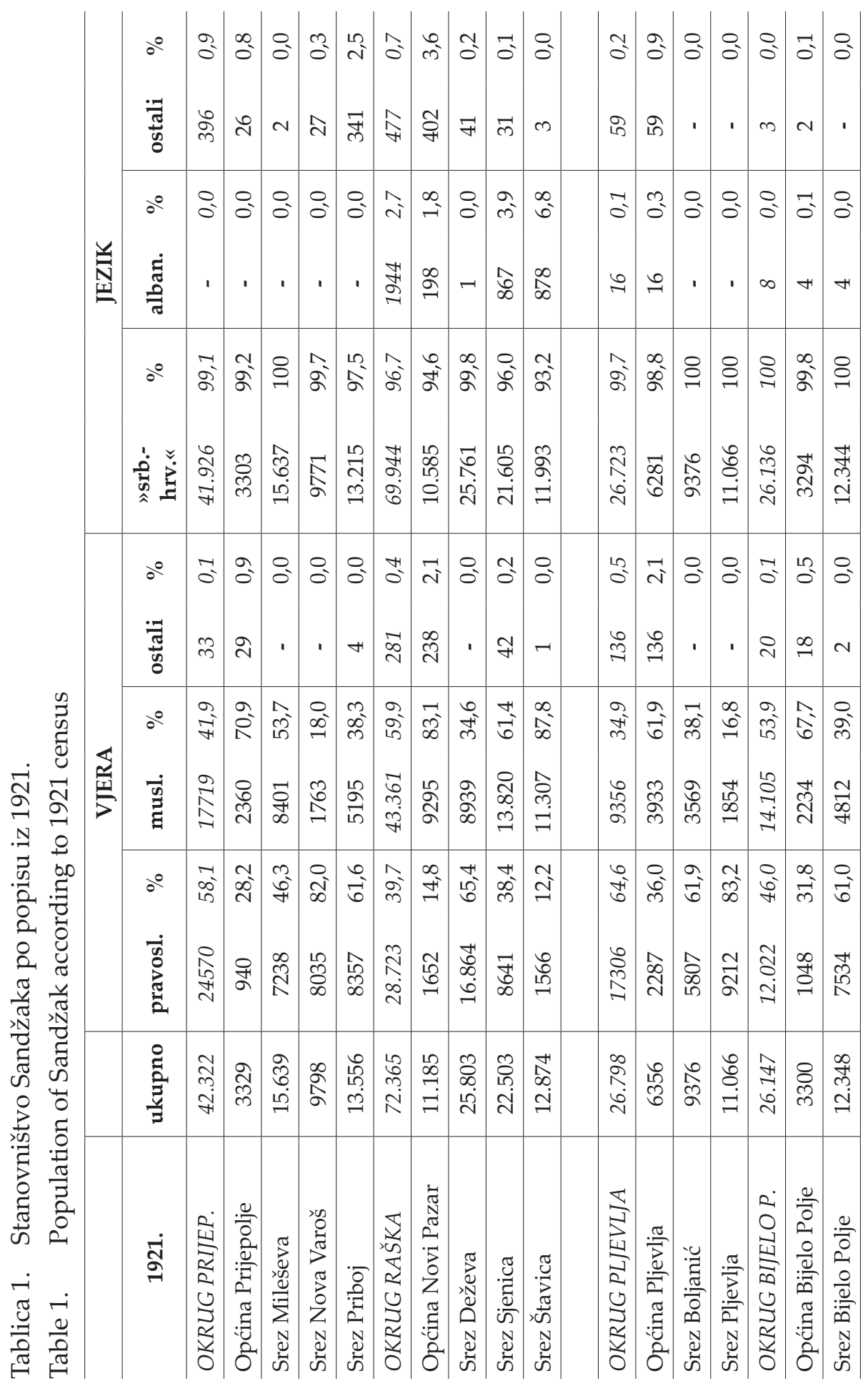




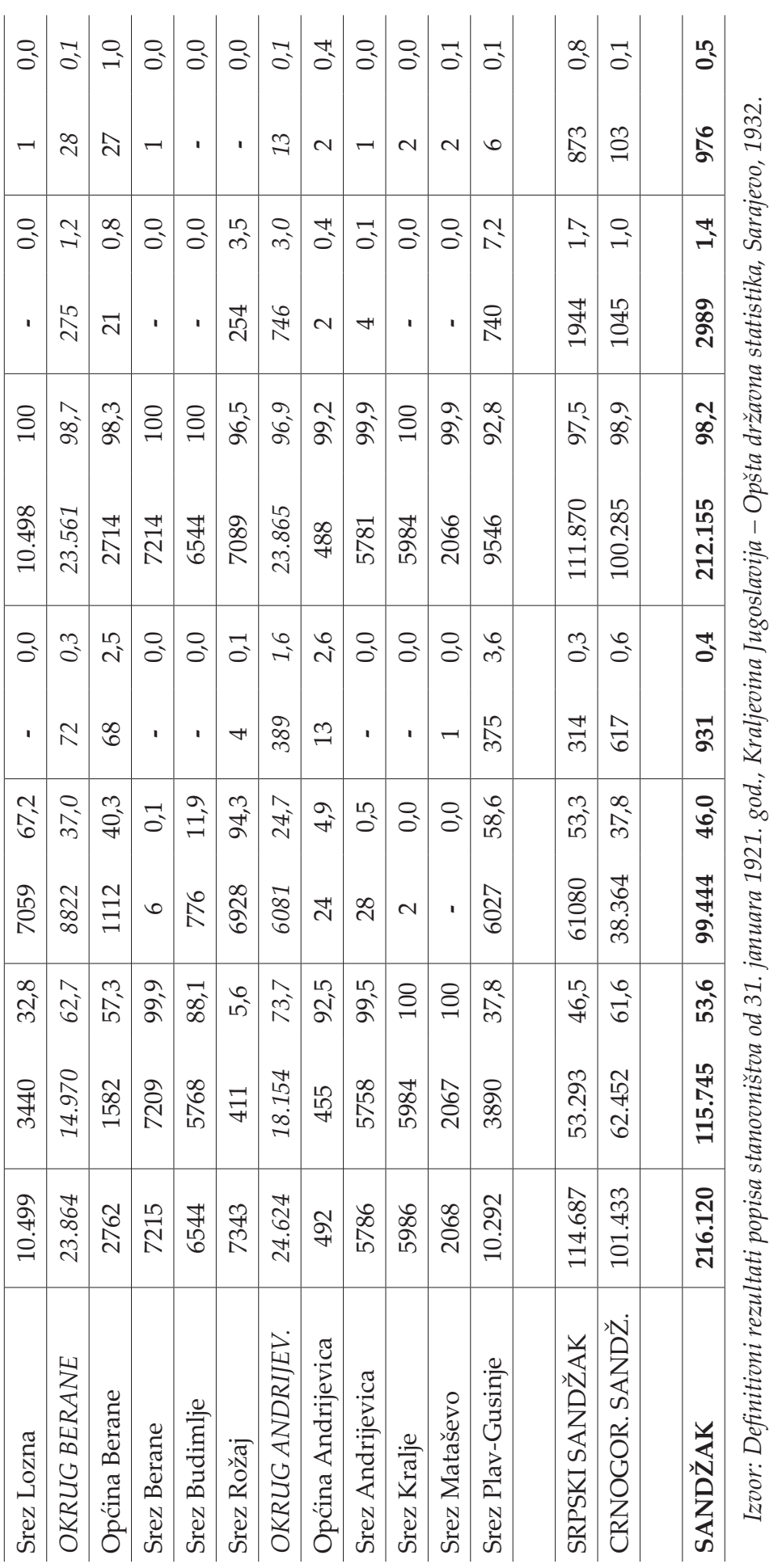




\subsection{Popis iz 1931.}

U vrijeme provođenja popisa iz 1931. Sandžak je bio dijelom Zetske banovine. Prostorno se nalazio u okviru deset srezova, pri čemu je svaki od njih uključivao niz manjih općina te jedan ili više gradova koji su predstavljali zasebne upravne cjeline.

I u kontekstu ovog popisa do podataka o etničkoj pripadnosti može se doći samo posredno. Budući da je 1931. registriran zanemarivi broj Albanaca i »ostalih«, broj Srba/Crnogoraca i Bošnjaka ne bi značajnije odudarao od ukupnog broja pravoslavaca, odnosno muslimana. Prvih je moglo biti oko 154.000, a drugih oko 107.000. Iz popisnih je rezultata vidljivo da je bošnjačka zajednica između 1921. (96.000) i 1931. (107.000) porasla tek za nekih 11\%. Nasuprot tome broj Bošnjaka BiH između 1921. (588.000) i 1931. (718.000) porastao je za 22\% (v. Marić, 1996: 89, 119). Da je za toliko uvećana bošnjačka zajednica u Sandžaku, imala bi oko 117.000 pripadnika, tj. bila bi brojnija za desetak tisuća ljudi. Uzroci takva stanja bili su različiti, no zasigurno su tadašnja iseljavanja u Tursku, koja se masovno nastavljaju do kraja šezdesetih, presudno utjecala na njeno brojčano slabljenje (Bandžović, 1991: 110). 


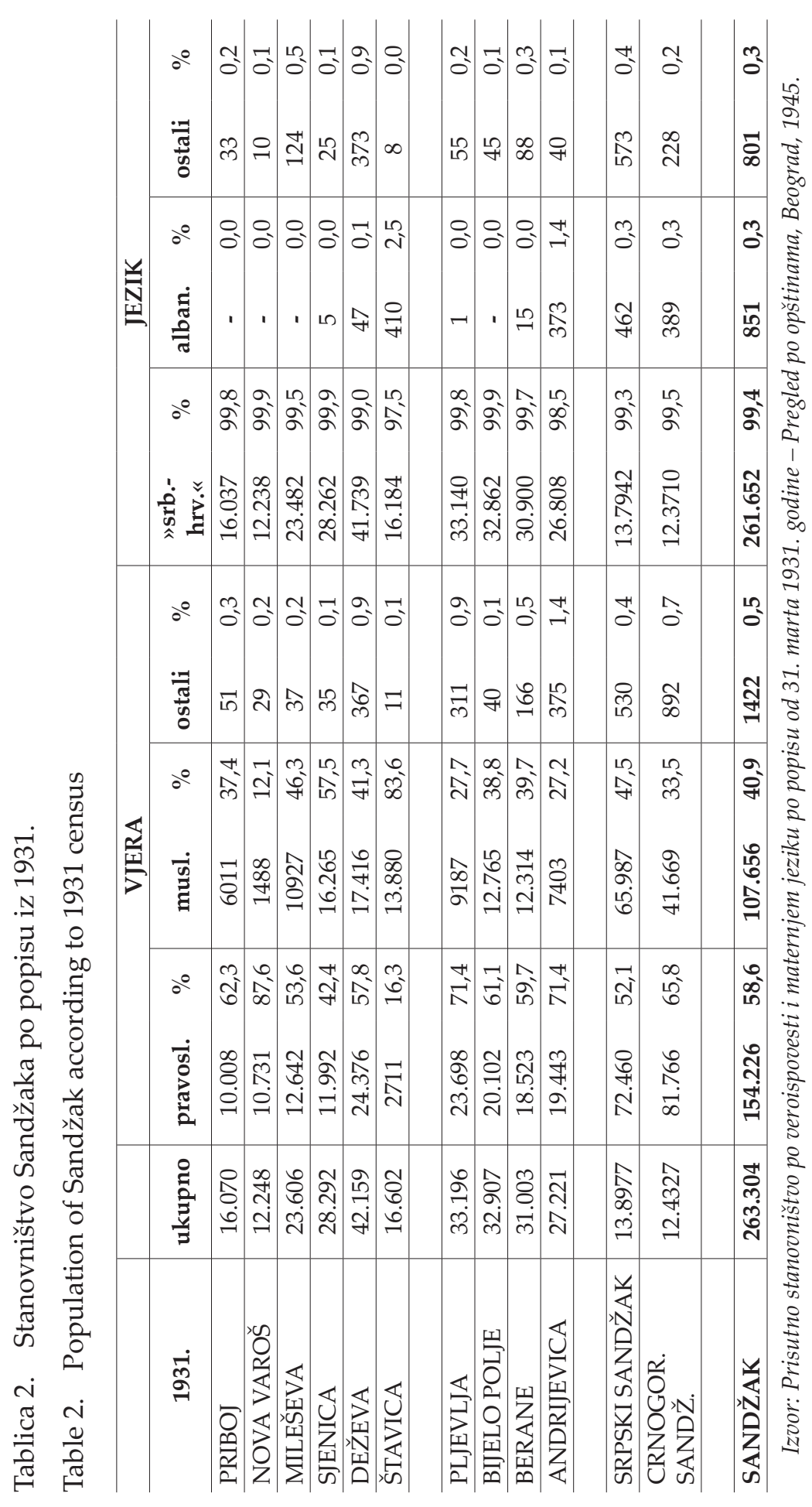




\section{BOŠNJACI SANDŽAKA U POPISIMA 1948., 1953. I 1961.}

Kako je naznačeno, unatoč tome što se komunistička vlast načelno odnosila prema Bošnjacima kao posebnoj etničkoj cjelini, proces njezina priznanja kao samosvojne nacije bio je relativno dug. Taj je realitet ostavio traga i u prvim poslijeratnim popisima. Tako su se u prvom popisu nakon Drugoga svjetskog rata, onom iz 1948., Bošnjaci mogli izjasniti kao »neopredijeljeni muslimani« (u tablici 3: »n-M«), u onom iz 1953. kao »Jugoslaveni-neopredijeljeni« (u tablici 4: »n-J«), a u popisu iz 1961. kao »Muslimani u smislu etničke pripadnosti« (u tablici 5: »etn-M«). Tek su u drugoj polovini šezdesetih donesene političke odluke koje potvrđuju činjenicu da je riječ o posebnoj naciji, kojoj se određuje i nacionalno ime »Muslimani« (»Muslimani u smislu narodnosti«). Stoga se u popisima iz 1971., 1981. i 1991. Bošnjaci tako i očituju (u tablicama 6, 7 i 8: »M«).

\subsection{Popis iz 1948.}

Po upravnoj podjeli aktualnoj tijekom provođenja popisa iz 1948., Sandžak je bio razdijeljen na srezove, s tim da su dva grada Novi Pazar i Pljevlja formirala posebne upravne cjeline. Nekadašnji srez, a buduća općina Nova Varoš u ovo je vrijeme srez Zlatarski.

Kod popisa iz 1948. Bošnjaci su imali mogućnost izjasniti se kao »neopredijeljeni muslimani«. U BiH se od 885.689 Bošnjaka njih 788.403 izjasnilo u tom smislu, 71.991 kao Srbi te 25.295 kao Hrvati (Mrđen, 2002: 87). Dakle gotovo $90 \%$ očitovalo ih se kao »neopredijeljeni muslimani«. Iz priložene je tablice vidljivo da je među sandžačkim Bošnjacima ta mogućnost iskorištena u perifernoj mjeri. Tako se izjasnilo tek 3885 ljudi, i to ponajviše u srpskom dijelu Sandžaka, u kojem se velika većina Bošnjaka opredijelila za srpsku nacionalnost. U crnogorskom dijelu Bošnjaci su se u nacionalnom smislu gotovo u potpunosti očitovali kao Crnogorci. Za daljnji uvid u etničke prilike važno je istaći da se 1948. tek petnaest osoba na Sandžaku izjasnilo Turcima. 


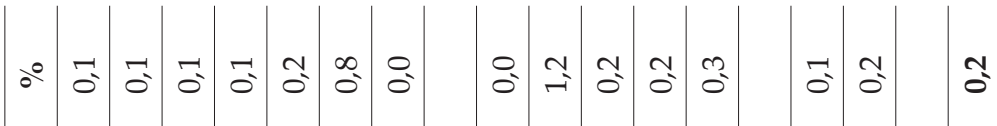

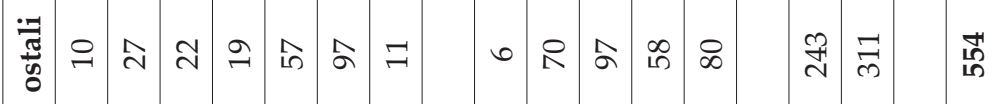

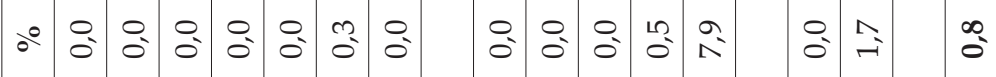

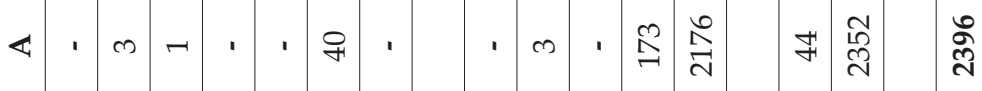

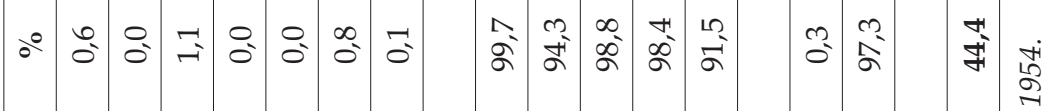

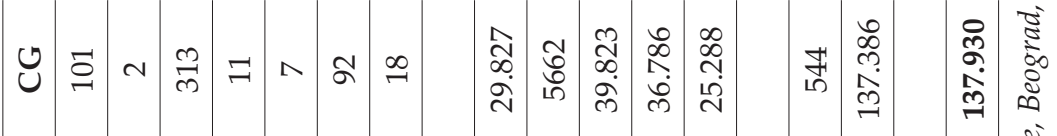

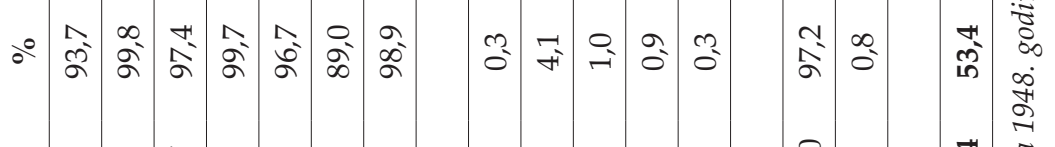

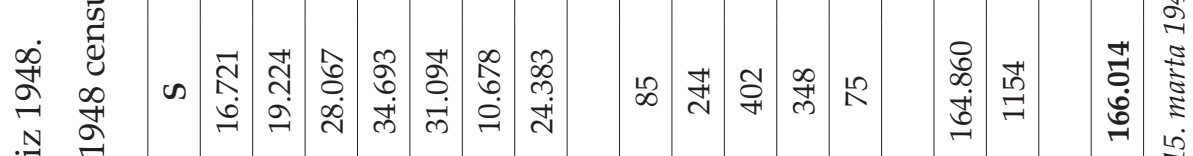

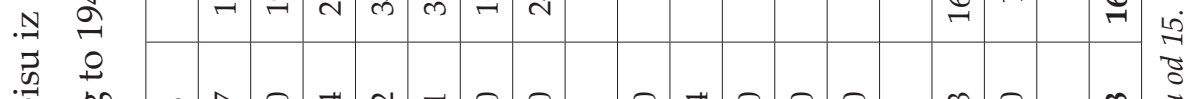

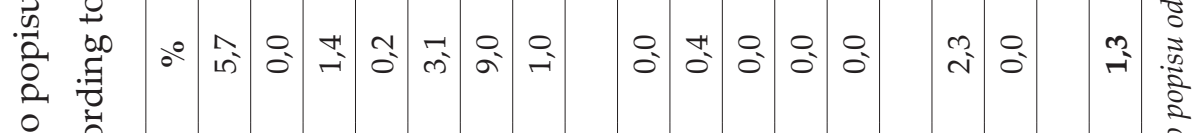

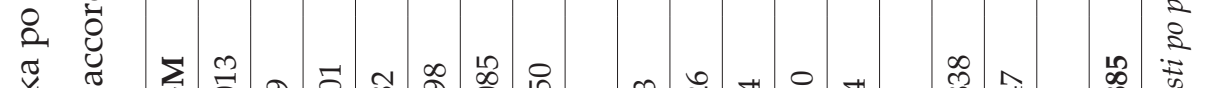

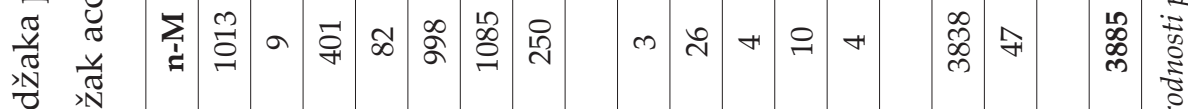

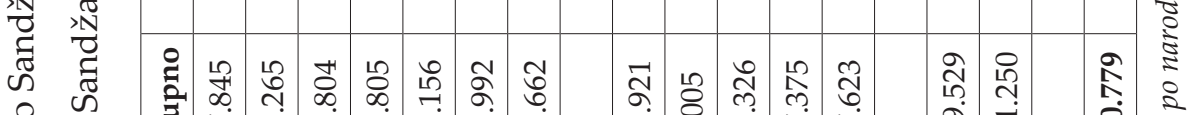

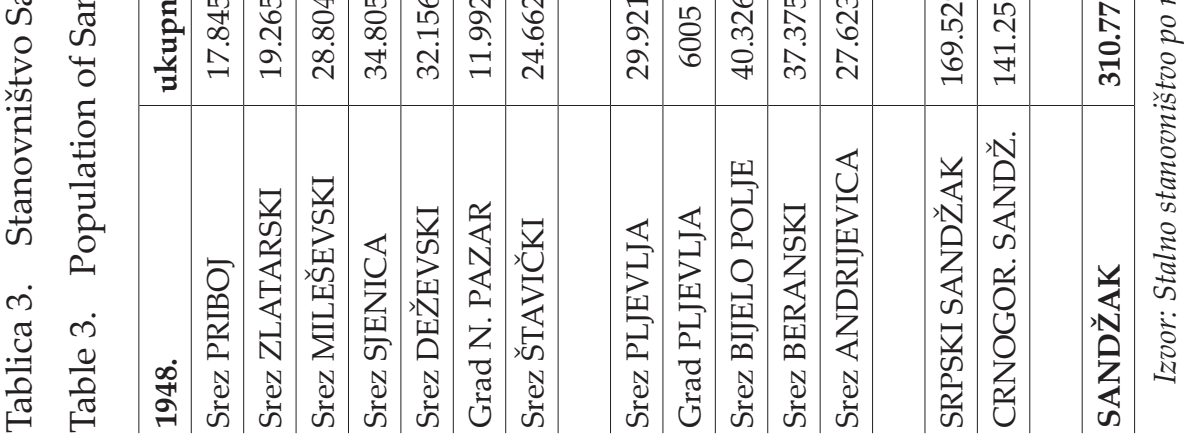




\subsection{Popis iz 1953.}

Tijekom popisa iz 1953. Sandžak je bio dijelom devet srezova od kojih se svaki sastojao od niza manjih općina. Gradovi Novi Pazar i Pljevlja, za razliku od 1948., sada su dijelom srezova Deževa odnosno Pljevlja. Grad Berane $\mathrm{u}$ međuvremenu je postao Ivangrad te $\mathrm{u}$ ovom popisu imamo $\mathrm{i}$ istoimenu upravnu cjelinu. Njoj najvećim dijelom pripada i teritorij nekadašnjeg sreza Andrijevica. Nekadašnji srez, a buduća općina Nova Varoš i nadalje je srez Zlatarski.

Prilikom popisa iz 1953. Bošnjaci su imali mogućnost izjasniti se kao »Jugoslaveni-neopredijeljeni« kako bi izbjegli identifikaciju s kojom od drugih južnoslavenskih nacija. Od ukupno 942.505 Bošnjaka unutar BiH, njih 891.800 opredijelilo se na taj način, 35.228 kao Srbi, a 15.477 kao Hrvati (Ivanović, 2009: 10). Dakle gotovo $95 \%$ Bošnjaka BiH tada se očitovalo kao »Jugoslaveni-neopredijeljeni«. U Sandžaku je drugačija situacija. U njegovu srpskom dijelu Bošnjaci se glavninom opredjeljuju za tu odrednicu, veliki dio njih, tj. 14.987, izjašnjava se Turcima, dok je opredjeljenje za srpsku nacionalnost krajnje reducirano. $S$ druge strane, u crnogorskom dijelu Sandžaka Bošnjaci se i nadalje velikom većinom izjašnjavaju kao Crnogorci, u relativno maloj mjeri kao »Jugoslaveni-neopredijeljeni«, dok identifikacija s Turcima ima minornu važnost. Samo izjašnjavanje za tursku nacionalnost bilo je kod ovog i naredna dva popisa u uskoj vezi s tadašnjim masovnim iseljavanjima sandžačkoga bošnjačkog življa u Tursku. Prihvaćanje turske nacionalne identifikacije trebalo je olakšati nadilaženje restrikcija koje su stajale na putu iseljavanja iz domovine i useljavanja u navedenu zemlju (v. Pačariz, 2016: 157-160). 


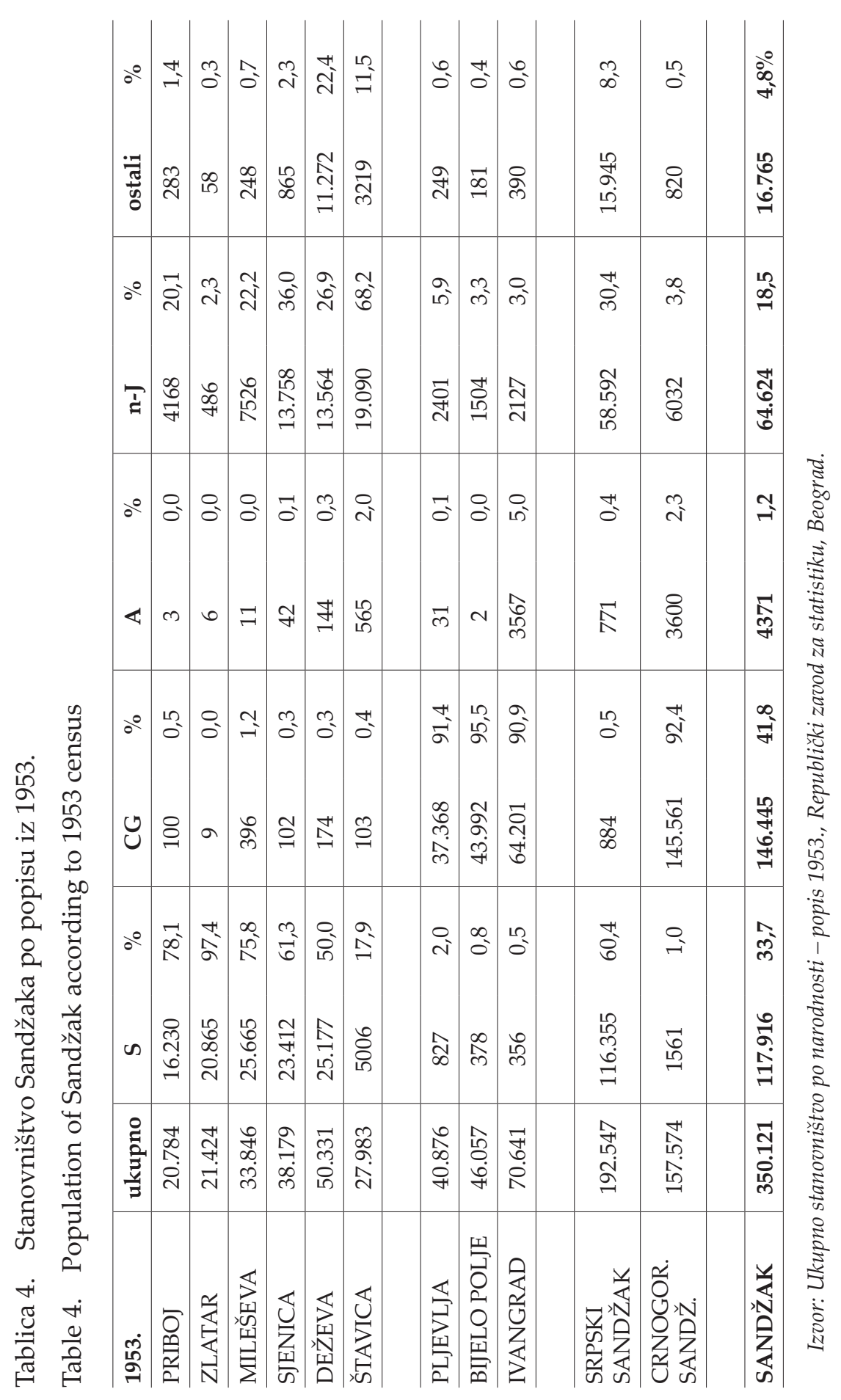




\subsection{Popis iz 1961.}

Do popisa iz 1961. Sandžak stječe upravno-teritorijalne značajke koje će ostati nepromijenjenima praktično do 1991. Podijeljen je na jedanaest općina, pri čemu su dvije, Rožaj i Plav, nastale izdvajanjem iz nekadašnjeg ivangradskog sreza. Također, u međuvremenu su izmijenjeni i nazivi pojedinih cjelina, te od ovog popisa imamo općine Prijepolje (prije Mileševa), Novi Pazar (Deževa), Tutin (Štavica) i Nova Varoš (Zlatar).

Popis iz 1961. ostavljao je Bošnjacima priliku da se izjasne kao »Muslimani u smislu etničke pripadnosti «. U BiH se od 1.118.130 Bošnjaka tako izjasnilo njih 842.247 ili 75,3\%, dok ih se 275.883 ili $24,7 \%$ očitovalo kao i u prethodnom popisu, tj. kao »Jugoslaveni nacionalno neopredijeljeni«. Sveukupno, za novu mogućnost kao i za onu koja im je ostavljena i u prethodnom popisu, dakle za opcije koje ih nisu poistovjećivale ni s kojom od drugih južnoslavenskih nacija, u popisu 1961. opredijelila se gotovo cjelina bosanskohercegovačkih Bošnjaka. Među sandžačkima je situacija drugačija, no sve su jasnije tendencije koje ih po tom pitanju približavaju sunarodnjacima u $\mathrm{BiH}$. $\mathrm{U}$ njegovu srpskom dijelu većina Bošnjaka izjašnjava se »Muslimanima u smislu etničke pripadnosti«, dok se u crnogorskom u podjednakoj mjeri opredjeljuju za tu opciju i za nacionalno crnogorstvo. I u ovom popisu znatni dio sandžačkih Bošnjaka, gotovo njih 15.500, izjasnio se Turcima, i to iznova velikom većinom u njegovu srpskom dijelu (Rudić i Stepić, 1995; Rudić, 1995). 


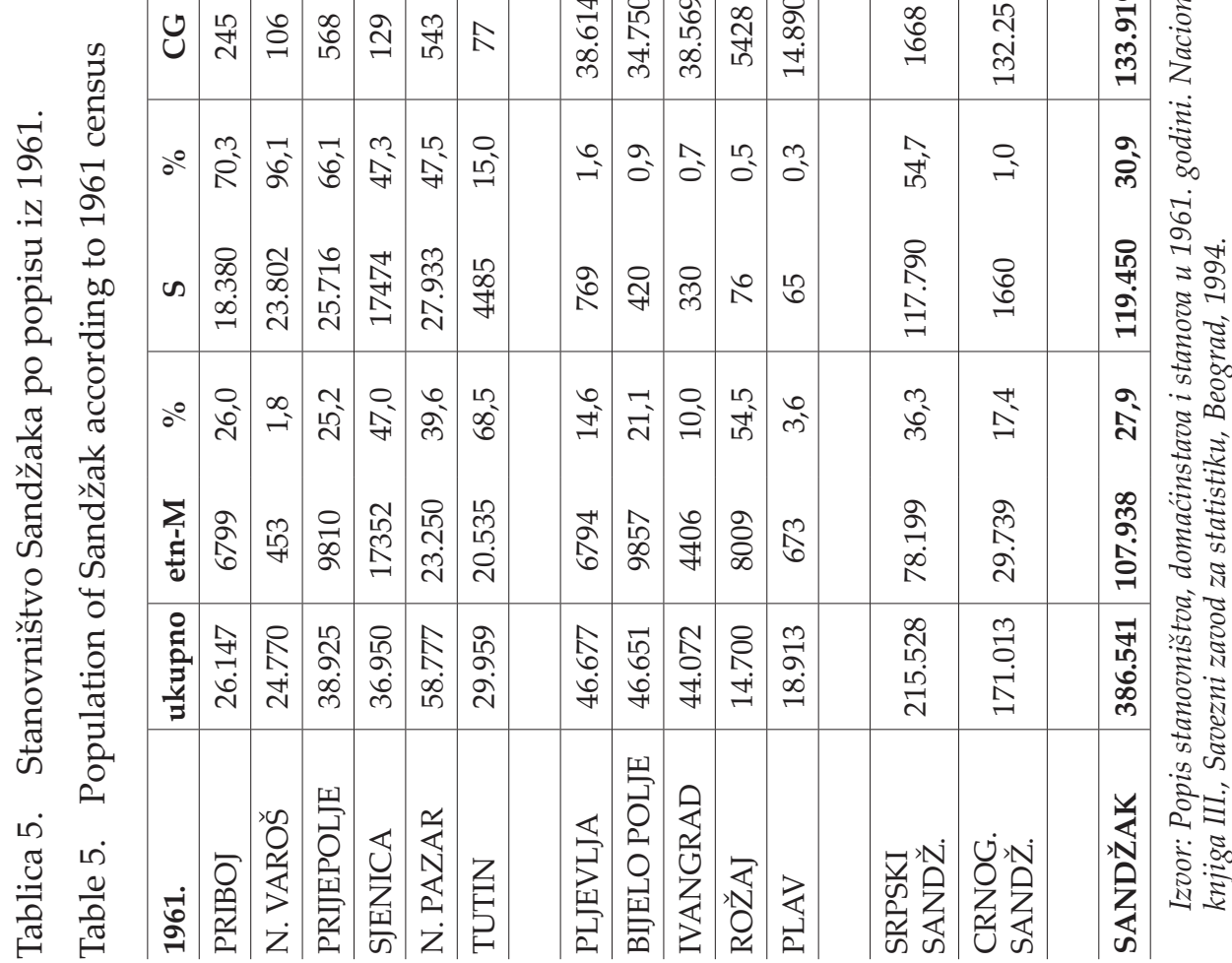

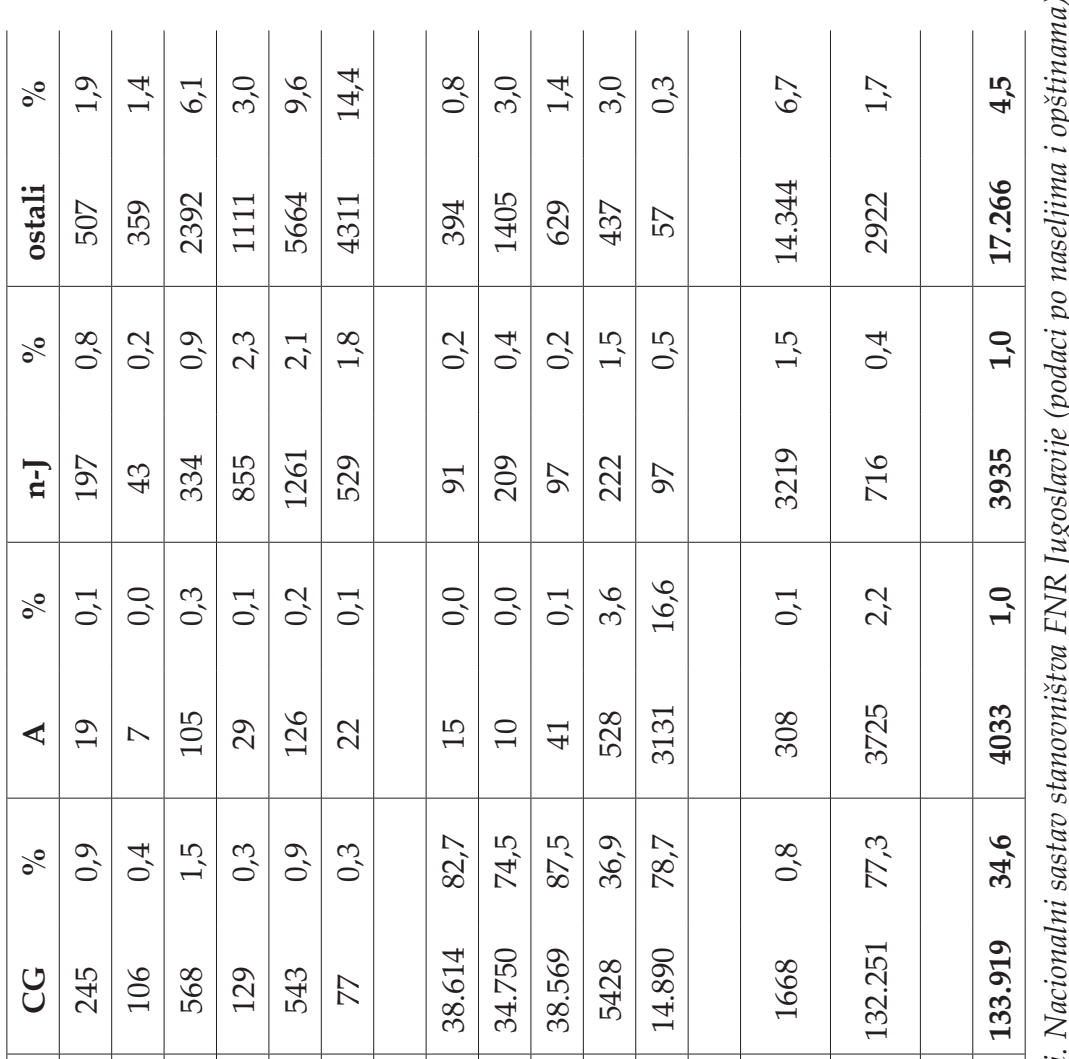




\section{BOŠNJACI SANDŽAKA U POPISIMA 1971., 1981. I 1991.}

Do kraja šezdesetih, kako je već rečeno, politički je napokon odlučeno da Bošnjaci predstavljaju posebnu naciju, kojoj je određen i naziv: »Muslimani«. Jasno, taj je realitet uvažen i prilikom provođenja popisa iz 1971., u kojem su se Bošnjaci mogli izjasniti kao »Muslimani u smislu narodnosti«. Ista je mogućnost vrijedila i kod popisa iz 1981. te onog iz 1991. Upravnoteritorijalna podjela prilikom provođenja popisa iz 1961. bila je ista 1971. i 1981. Donekle je izmijenjena do popisa iz 1991. Neposredno prije njegova provođenja, tj. 1990., od južnog je dijela općine Ivangrad (iznova) oblikovana općina Andrijevica.

\subsection{Popis iz 1971.}

Prilikom popisa iz 1971. gotovo cjelina Bošnjaka iz BiH, njih 1.482.430, izjasnila se Muslimanima. Napokon im je po tom pitanju identičan bošnjački živalj Sandžaka, koji se golemom većinom također izjasnio tako. Izuzetak je tek u tome što se manji dio, sukladno dotadašnjoj tradiciji, očitovao kao Turci. Riječ je bila o svega 4639 ljudi, najvećim dijelom nastanjenih u njegovu srpskom dijelu. Zajedno s tada deklariranim Turcima, u Sandžaku je 1971. obitavao 174.751 Bošnjak, čineći 42,2\% od njegove ukupne populacije. 


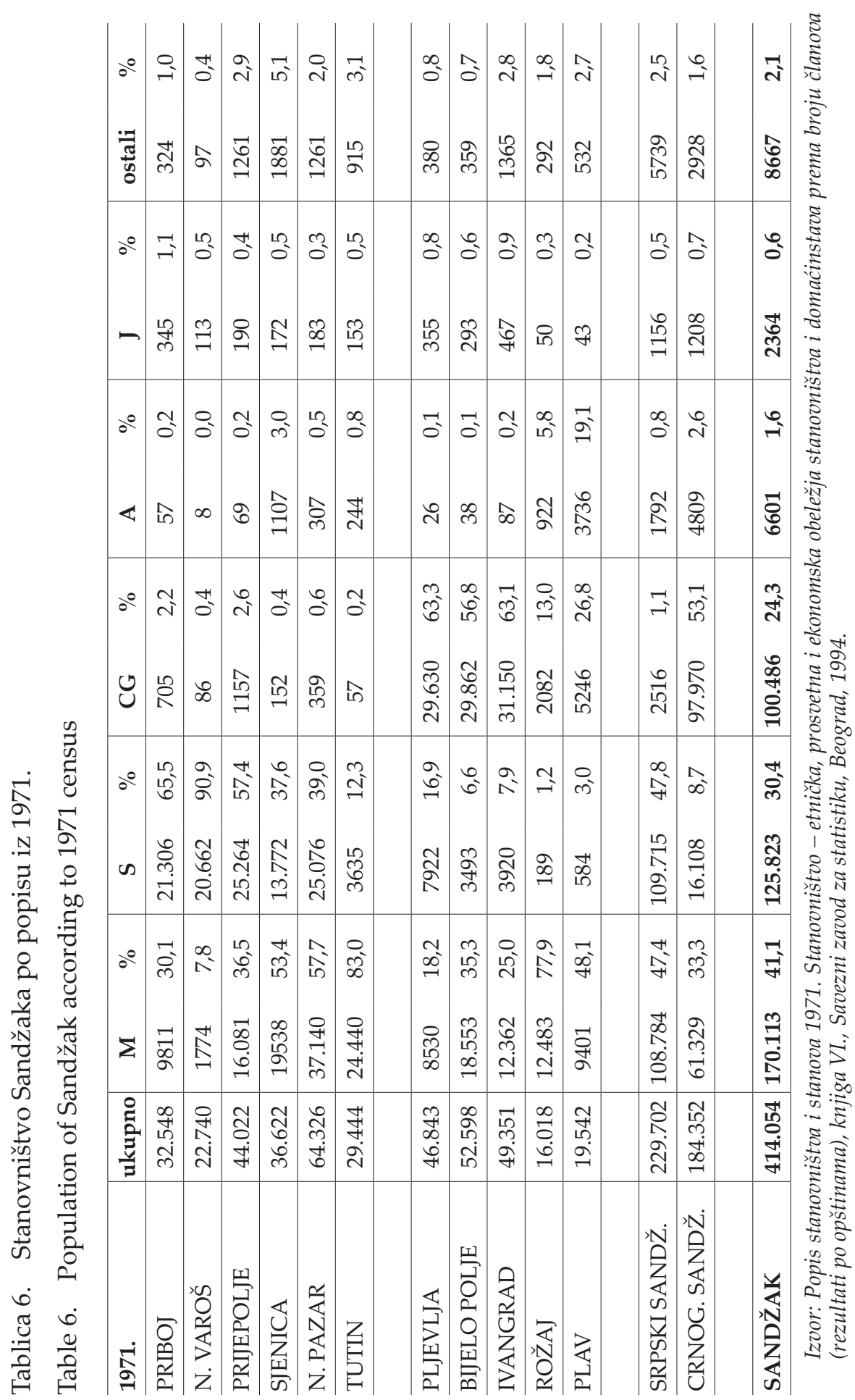




\subsection{Popis iz 1981.}

Popis iz 1981. pokazao je gotovo potpuno ujednačivanje Bošnjaka iz BiH i Sandžaka po pitanju nacionalne identifikacije. Zapravo, u ovom, ali i sljedećem popisu Bošnjaci iz BiH iskazuju veću razinu distanciranja od samosvojne nacionalne odrednice. Naime 1981. u BiH je bilo 1.629.924 Muslimana. No čak 326.280 ili $8 \%$ stanovnika te republike izjasnilo se »Jugoslavenima«. Među njima je pored Hrvata i Srba svakako bio i znatni dio Bošnjaka. Nasuprot tome u Sandžaku se manje od 2\% stanovništva, u osnovi Srba, Crnogoraca i Bošnjaka, izjasnilo »Jugoslavenima«. Također, nekad relativno brojno izjašnjavanje sandžačkih Bošnjaka za tursku nacionalnost izgubilo je na važnosti do popisa 1981. 


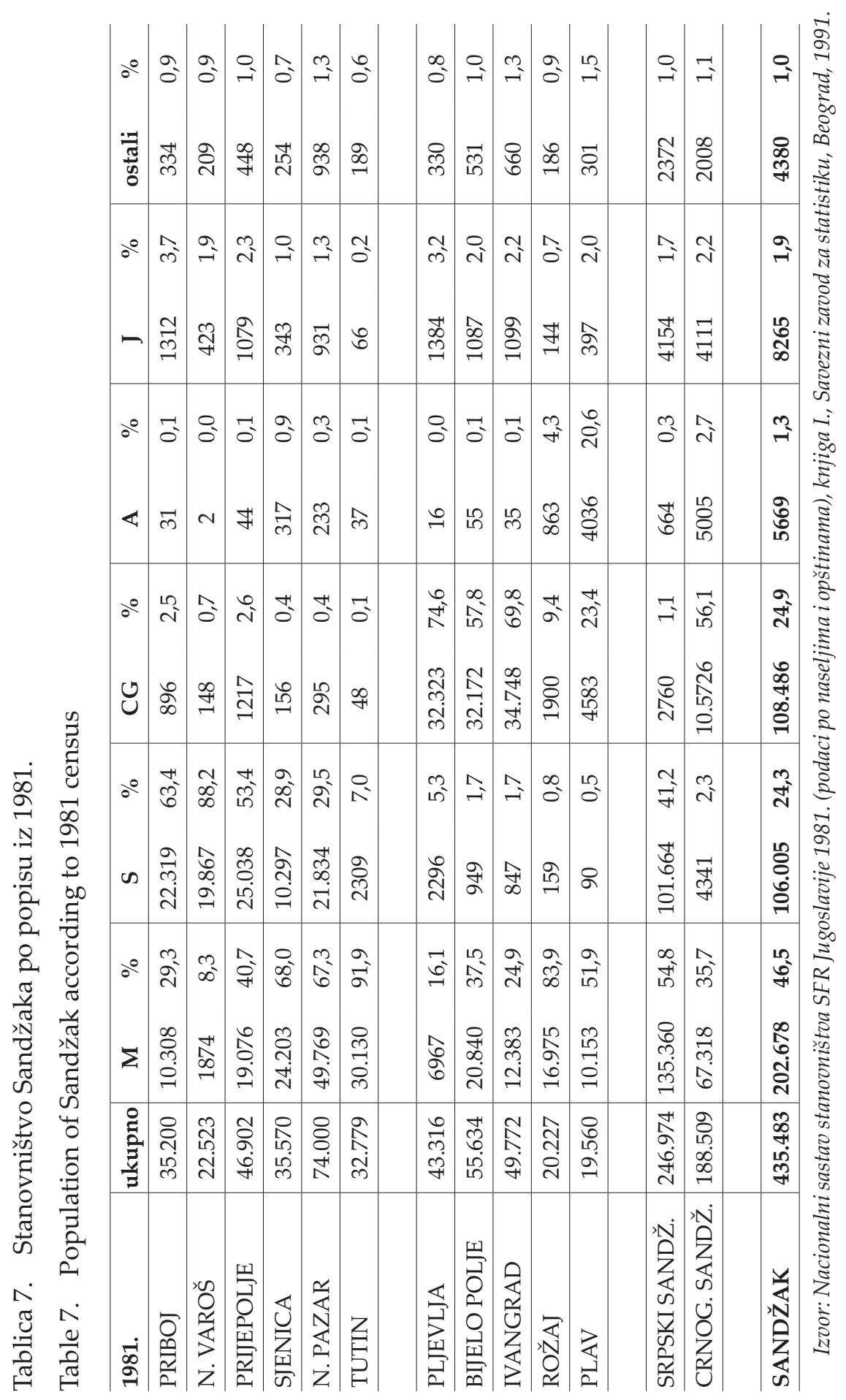




\subsection{Popis iz 1991.}

Popis iz 1991. uvelike je potvrdio realitete koji su se očitovali deset godina prije. Bošnjaci u BiH i na Sandžaku u nacionalnom se smislu praktično istovrsno izjašnjavaju. U BiH je tada evidentirano 1.902.956 Muslimana. No iznova se veliki dio građana te republike, i to u uvjetima raspada SFRJ, izjasnio »Jugoslavenima", odnosno bilo ih je 242.682 ili 5,5\% od ukupnog stanovništva (Stanovništvo Bosne i Hercegovine - narodnosni sastav po naseljima, 1995: 9). $S$ druge strane, udio »Jugoslavena« u Sandžaku ne prelazi 1\%. 


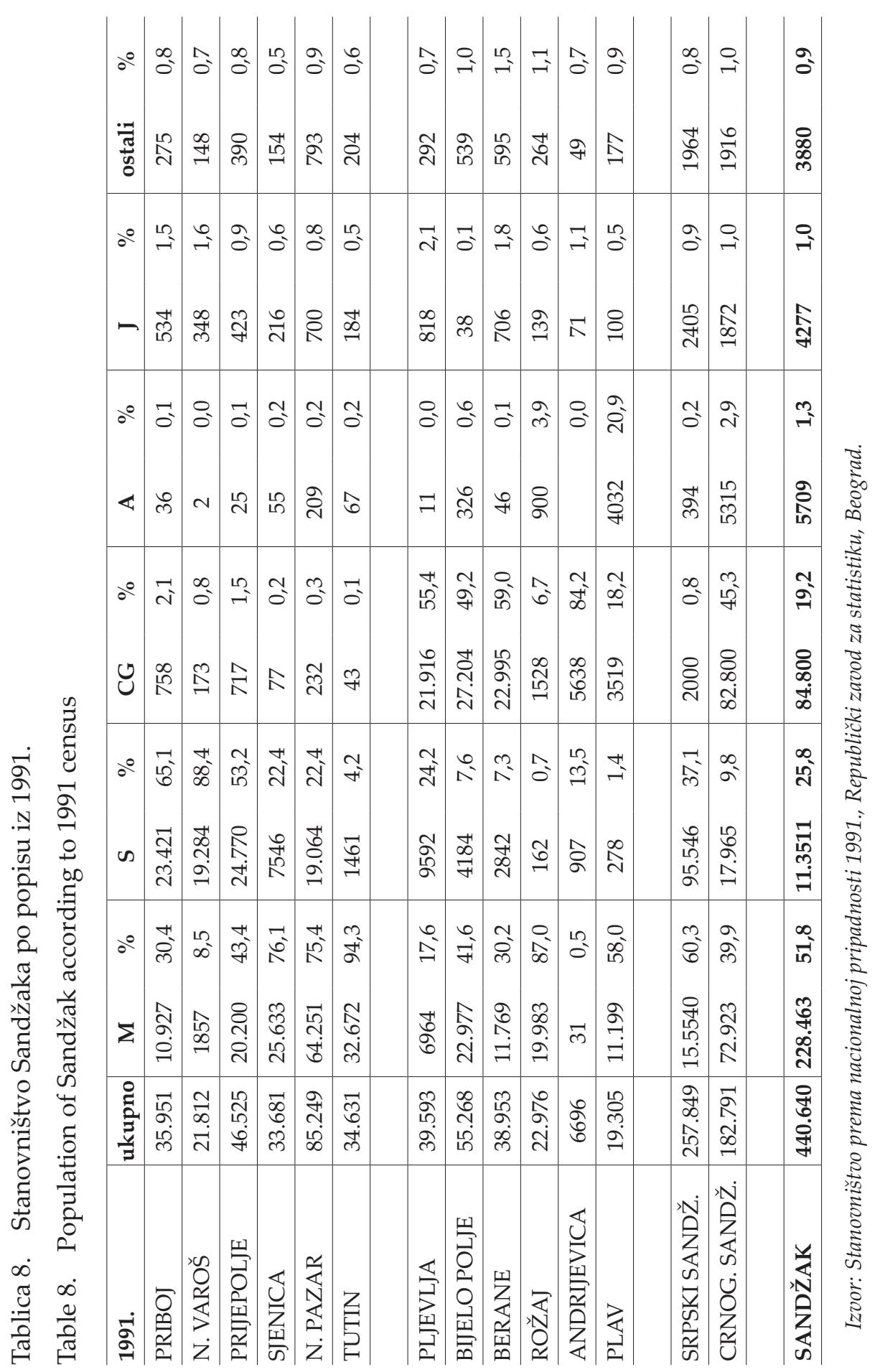




\section{BOŠNJACI SANDŽAKA U POSTJUGOSLAVENSKIM POPISIMA 2002./2003. I 2011.}

Nakon raspada Socijalističke Federativne Republike Jugoslavije 1991., Srbija i Crna Gora oblikovale su Saveznu Republiku Jugoslaviju (SRJ), koja je 2003. preimenovana u Državnu zajednicu Srbija i Crna Gora. Poslije crnogorskog izjašnjavanja za neovisnost 2006. ta zajednica prestaje postojati te se na političkoj pozornici pojavljuju samostalna Crna Gora i Srbija. Popis koji se u SRJ trebao održati 2001., tj. deset godina nakon onog iz 1991., bio je odgođen te je u Srbiji proveden 2002., a u Crnoj Gori 2003. S obzirom na tu činjenicu nemoguće je dati točan ukupni broj stanovništva ili pojedinih nacionalnih zajednica u Sandžaku bilo za 2002., bilo za 2003. Kod idućih popisa taj problem ne postoji jer su se u obje zemlje odvili 2011. U BiH je prvi popis nakon 1991. proveden tek 2013. Sukladno izmjeni nacionalnog naziva »Musliman « u »Bošnjak «, koja je muslimanskom/bošnjačkom korpusu prihvaćena 1993., popis iz 2013. registrirao je 1.769.592 Bošnjaka i 12.121 Muslimana, tj. zajedno 1.781.713 (Stanovništvo prema etničkoj / nacionalnoj pripadnosti - detaljna klasifikacija, 2016). U odnosu na taj broj udio Muslimana uistinu je bio periferan, 0,7\%. Kako ćemo vidjeti, po tom je pitanju situacija na Sandžaku bila donekle drugačija.

\subsection{Popis iz 2002. (Srbija) i 2003. (Crna Gora)}

Po popisu iz 2002. u srpskom je dijelu Sandžaka živjelo 134.128 Bošnjaka i 8.222 Muslimana te ih je zajedno bilo 142.350. U odnosu na taj broj izjašnjeni Bošnjaci imali su udio od 94,22\%, a Muslimani od 5,78\%. U ukupnom stanovništvu srpskog dijela Sandžaka Bošnjaci i Muslimani imali su kao cjelina (142.350) udio od 60,43\%. S druge strane, po popisu iz 2003. u crnogorskom je dijelu Sandžaka živio 44.341 Bošnjak i 15.456 Muslimana te ih je zajedno bilo 59.797. U odnosu na taj broj izjašnjenih je Bošnjaka bilo 74,15\%, a Muslimana 25,85\%. U ukupnom stanovništvu crnogorskog Sandžaka Bošnjaci i Muslimani imali su kao cjelina (59.797) udio od 36,59\%.

Ako sagledamo prostor cjelokupnog Sandžaka, što se može činiti samo uvjetno s obzirom na godinu dana razmaka između provedbe srpskog $i$ crnogorskog popisa, u njemu je živjelo 178.469 Bošnjaka te 23.678 Muslimana, kojih je zajedno bilo 202.147. U odnosu na taj broj Bošnjaci su imali udio od $88,29 \%$, a Muslimani 11,71\%. U ukupnom stanovništvu Sandžaka Bošnjaka i Muslimana (202.147) bilo je $50,66 \%$. 


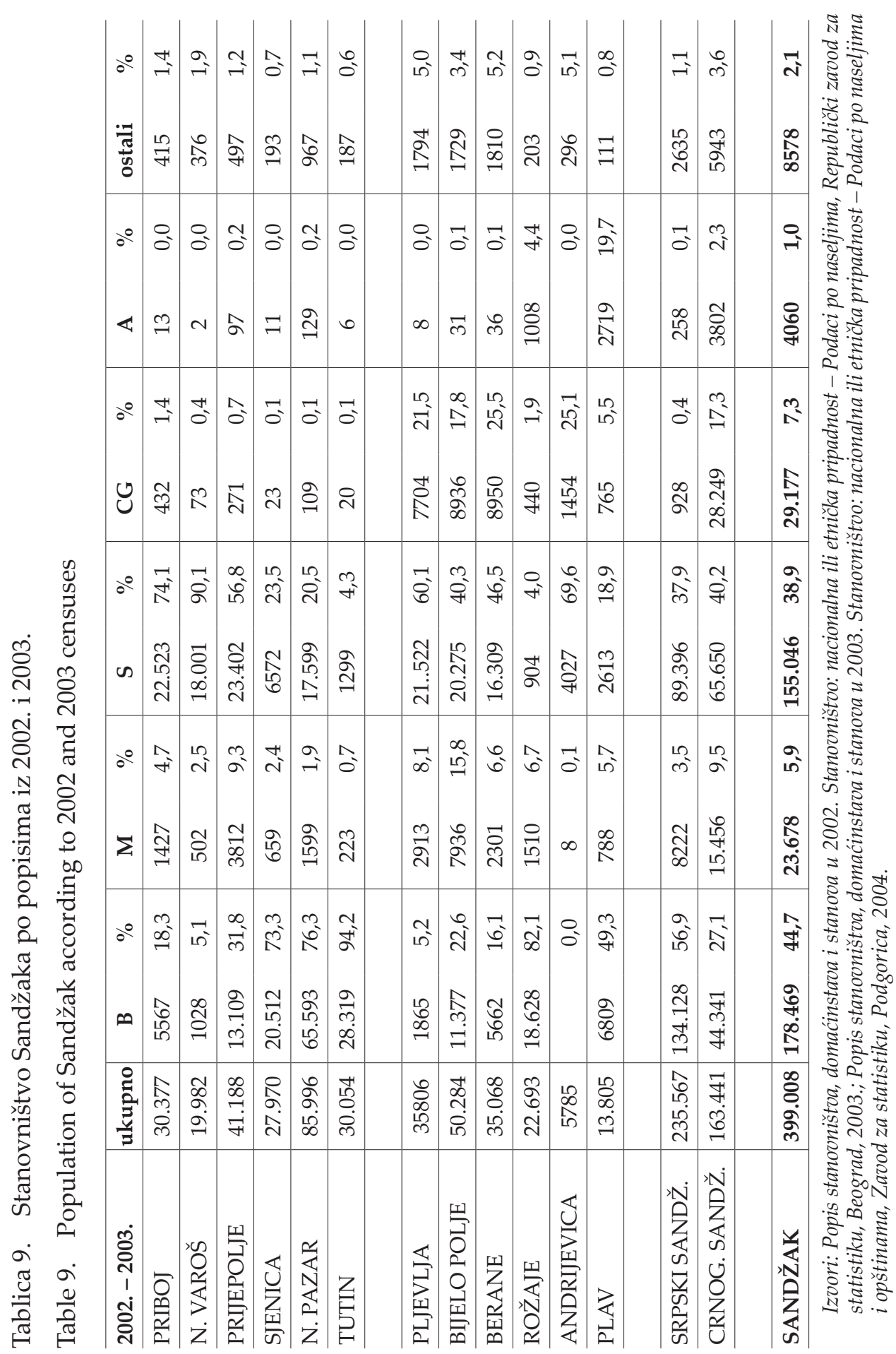


Kod popisa iz 2002./2003. uočljivo je znatno uvećanje broja građana koji su prilikom popisa registrirani kao »neizjašnjeni «, »neopredijeljeni« ili su svrstani u rubriku »nepoznato « (u tablici br. 9 ti su građani uključeni u brojčano veću skupinu »ostalih«/»Ost.«/). U srpskom Sandžaku broj takvih bio je 1541, a u crnogorskom čak 4965, dakle zajedno 6506. Moglo bi se iznijeti pretpostavku da je u tim slučajevima, kao i kod popisa iz 2011., najčešće riječ o pripadnicima bošnjačkog/muslimanskoga kruga. Primjerice u Pljevljima je 1991. bilo 17,6\% Muslimana, dok je 2003. pored 13,3\% Bošnjaka i Muslimana prisutno i 4\% neizjašnjenih/neopredijeljenih. U Bijelom Polju je 1991. bilo 41,6\% Muslimana, dok je 2003. registrirano 38,4\% Bošnjaka i Muslimana te 1,7\% neizjašnjenih/neopredijeljenih. Detekcija »stvarne« pripadnosti neizjašnjenih/ neopredijeljenih poseban je i složen istraživački problem koji između ostaloga zahtijeva usporedbu s popisnim podacima o vjerskoj, pa i jezičnoj identifikaciji (v. Šarkinović, 2004: 201-209). One bi uz ostalo mogle pružiti i preciznije pokazatelje o teritorijalnoj distribuciji 11.710 muslimana Crne Gore koji su se 2003. očitovali kao Crnogorci (Đečević, Vuković-Ćalasan i Knežević, 2017: 146).

Mada pitanje izjašnjavanja za srpsku i crnogorsku nacionalnost, ako nije $\mathrm{u}$ vezi s očitovanjem Bošnjaka, nije predmet ovoga rada, crnogorski popis iz 2003. pokazao je jednu posve novu i snažno izraženu pojavu. Od tog popisa znatni dio nekadašnjih Crnogoraca izjašnjava se kao Srbi. Tako je 2003. u crnogorskom dijelu Sandžaka Srba bilo 65.650, a Crnogoraca 28.249, zajedno 93.899, pri čemu je udio Srba u tom broju iznosio 69,91\%, a Crnogoraca 30,09\%. U crnogorskom su Sandžaku Srbi i Crnogorci 2003. (93.899) predstavljali $57,45 \%$ od ukupnog stanovništva.

\subsection{Popis iz 2011.}

Po popisu iz 2011. u srpskom je dijelu Sandžaka živjelo 142.373 Bošnjaka i 12.441 Musliman te ih je zajedno bilo 154.814. U odnosu na taj broj izjašnjenih je Bošnjaka bilo 91,96\%, a Muslimana 8,04\%. U ukupnom stanovništvu srpskog dijela Sandžaka Bošnjaka i Muslimana (154.814) bilo je 64,83\%. U crnogorskom je dijelu Sandžaka živjelo 46.813 Bošnjaka i 11.459 Muslimana, tj. ukupno 58.272. U odnosu na taj broj izjašnjenih je Bošnjaka bilo 80,34\%, a Muslimana 19,66\%. U ukupnom stanovništvu crnogorskog Sandžaka Bošnjaka i Muslimana (58.272) bilo je 38,35\%.

U Sandžaku kao cjelini živjelo je 2011. godine 189.186 Bošnjaka i 23.900 Muslimana te ih je zajedno bilo 213.086. U odnosu na taj broj izjašnjenih je Bošnjaka bilo 88,78\%, a Muslimana 11,22\%. U ukupnom stanovništvu Sandžaka Bošnjaka i Muslimana (213.086) bilo je 54,53\%. 


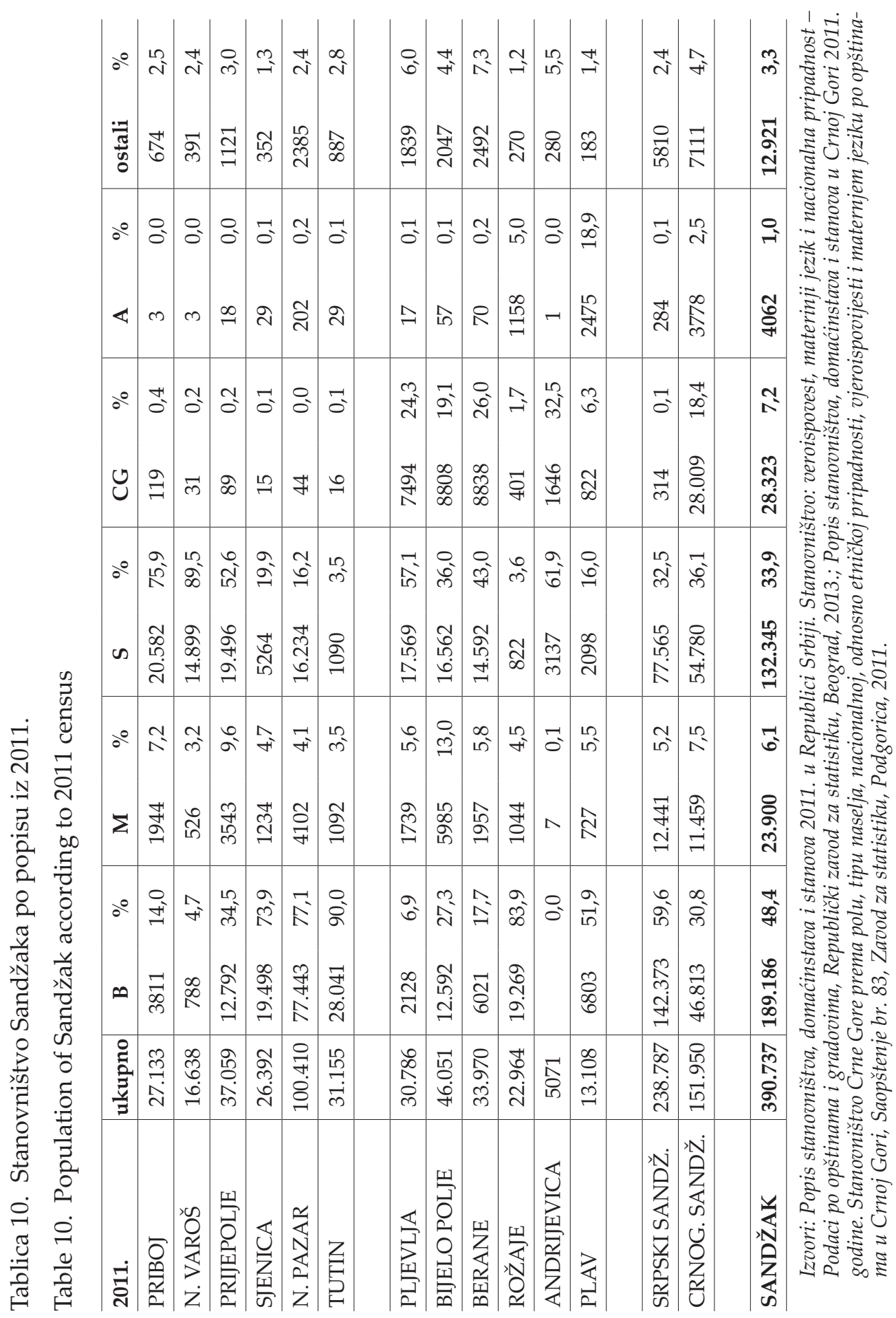


Kod popisa iz 2011. uočljivo je da je i nadalje relativno visok iznos onih stanovnika Sandžaka koji nisu nacionalno svrstani (u tablici br. 10 osobe koje se nisu nacionalno izjasnile uključene su u brojčano veću skupinu »ostalih" /»Ost.«/). Takvih je 2011., za razliku od prije, više u njegovu srpskom dijelu, gdje ih ima 3555, dok ih je u crnogorskom 2576, dakle zajedno 6131, tj. nešto manje nego u popisima iz 2002./2003. Istodobno, znatni se dio muslimana u Crnoj Gori i 2011. izjasnio Crnogorcima, odnosno njih 12.933 (Đečević, Vuković-Ćalasan i Knežević, 2017: 148). Veliki dio te populacije obitavao je i u crnogorskom dijelu Sandžaka, s tim da se bez temeljitih, već spomenutih analiza ne može ustvrditi u kojoj mjeri i na kojim područjima.

U crnogorskom dijelu Sandžaka 2011. živjelo je 54.780 Srba i 28.009 Crnogorca ili zajedno 82.789. U odnosu na taj broj Srba je bilo 66,17\%, a Crnogorca 33,83\%. U ukupnom stanovništvu crnogorskog Sandžaka Srba i Crnogorca (82.789) bilo je $54,48 \%$.

\section{ZAKLJUČNO RAZMATRANJE}

Mada je bošnjačka zajednica u Sandžaku integralni dio bošnjačke nacije, ona po nizu odrednica predstavlja njezin posebni dio, takav koji i u istraživačkom smislu zahtijeva pristup koji uvažava specifičnosti prilika u kojima se Sandžak nalazio ili nalazi. U ovome radu predstavljeni su rezultati svih popisa stanovništva kojima je bio obuhvaćen od 1921. do 2011. Uvid u rezultate tih popisa omogućuje stjecanje određene, više ili manje jasne slike o njegovim etničkim značajkama, koje smo primarno doveli u kontekst razmatranja bošnjačkog segmenta. Pritom je glavni cilj rada bio usporedba podataka o etničkom, tj. nacionalnom izjašnjavanju, prisutnom u popisima nakon Drugoga svjetskog rata, između Bošnjaka BiH i Sandžaka te između Bošnjaka njegova srpskog i crnogorskog dijela.

Premda je komunistička vlast načelno pristupala Bošnjacima kao posebnoj etničkoj cjelini, trebalo je proći dosta vremena da i politički potvrdi bošnjačku nacionalnu samobitnost. Taj se realitet odrazio i na razini prvih triju popisa u Socijalističkoj Jugoslaviji. U onom iz 1948. Bošnjaci su imali priliku izjasniti se kao »neopredijeljeni muslimani«. $\mathrm{U}$ BiH se tako izjasnilo gotovo $90 \%$ Bošnjaka. U Sandžaku je takvo izjašnjavanje bilo minorno te prisutno samo u njegovu srpskom dijelu, u kojem su se Bošnjaci u najvećoj mjeri izjasnili kao Srbi. U crnogorskom dijelu gotovo su se u potpunosti izjasnili kao Crnogorci.

Popis iz 1953. Bošnjacima je ostavljao mogućnost da se izjasne kao »Jugoslaveni-neopredijeljeni«, što je u BiH učinilo njih oko 95\%. U srpskom dijelu 
Sandžaka većina se Bošnjaka također izjasnila na taj način, no znatni ih se dio očitovao Turcima. Za razliku od srpskog dijela Sandžaka, u kojem izjašnjavanje Bošnjaka kao Srba gubi na važnosti, u njegovu crnogorskom dijelu oni se i nadalje uglavnom izjašnjavaju kao Crnogorci, s tim da su se i u ovom i u narednim popisima crnogorski Bošnjaci u vrlo maloj mjeri identificirali kao Turci.

Popis iz 1961. Bošnjacima je omogućivao da se iskažu kao »Muslimani u smislu etničke pripadnosti«. U BiH se za tu opciju kao i za onu koja im je u prethodnom popisu predstavljala alternativu (»Jugoslaveni-neopredijeljeni«) izjasnio gotovo ukupni bošnjački korpus. U srpskom dijelu Sandžaka velika većina Bošnjaka očitovala se »Muslimanima ...", ali ih se iznova znatni dio izjasnio Turcima. U crnogorskom dijelu bošnjačka se populacija 1961. u podjednakom iznosu očitovala »Muslimanima ... « te Crnogorcima.

Nakon što je krajem šezdesetih politički prihvaćena konstitucija nacije »Muslimana«, za tu su se odrednicu kod popisa 1971. odlučili gotovo svi Bošnjaci BiH i Sandžaka. U njegovu srpskom dijelu tek se manji dio njih i tada izjasnio Turcima. Za popise iz 1981. i 1991. znakovito je da potvrđuju pravilo iz 1971., s tim da se u BiH značajni dio Bošnjaka, zajedno s Hrvatima i Srbima, izjašnjava »Jugoslavenima«. U Sandžaku je takvo izjašnjavanje bilo minorno.

Time što su Bošnjaci 1993. prihvatili da svoj dotadašnji nacionalni naziv zamjene bošnjačkim nastaje nova situacija, koju registriraju i naknadni popisi. Naime u njima se, kako na tlu Srbije i Crne Gore tako i u BiH, prihvaća realitet nacionalnog bošnjaštva, ali i ostavlja mogućnost da se osoba izjasni kao »Musliman«. Po popisu iz 2002. u srpskom je dijelu Sandžaka od ukupnog broja izjašnjenih Bošnjaka i Muslimana ovih drugih bilo blizu 6\%, a u Crnoj Gori, po popisu iz 2003., čak $26 \%$. Prilikom tih popisa moglo se smatrati da dio izjašnjenih još uvijek nije adekvatno percipirao važnost promjena koje se odnose na nacionalno opredjeljenje, ali da će do toga s vremenom doći, slično kao što se u BiH 1961. znatni dio Bošnjaka nije opredijelio »Muslimanima u smislu etničke pripadnosti«, već sukladno prethodnom popisu »Jugoslavenima-neopredijeljenima«. Već $\mathrm{u}$ idućem popisu ta je »anomalija« u BiH nadiđena, ali u slučaju Sandžaka nije.

Kod popisa iz 2011. u njegovu je srpskom dijelu od ukupnog broja izjašnjenih Bošnjaka i Muslimana ovih drugih bilo 8\%, a u crnogorskom blizu 20\%. Nasuprot tome u prvom popisu koji se u BiH održao poslije 1991., tj. popisu iz 2013., u toj je zemlji od ukupnog broja izjašnjenih Bošnjaka i Muslimana ovih drugih bilo tek $0,7 \%$. Osim navedenoga indikativno je da se u Crnoj Gori, a time i u crnogorskom Sandžaku, kako 2003. tako i 2011., znatni dio musli- 
mana izjasnio Crnogorcima. U svakom slučaju, osobite prilike u kojima žive sandžački Bošnjaci iznova se odražavaju i kod popisnih očitovanja nacionalne pripadnosti, s tim da se ponovno uočavaju i razlike između Bošnjaka/ Muslimana njegova srpskog i crnogorskog dijela. Zašto je to tako, trebalo bi biti predmetom posebne analize.

\section{LITERATURA}

Banac, I. (1988). Nacionalno pitanje u Jugoslaviji. Zagreb: Globus.

Bandžović, S. (1991). Iseljavanje Muslimana iz Sandžaka. Sarajevo: Biblioteka Ključanin. Bertić, I. (ur.) (1987). Veliki geografski atlas Jugoslavije. Zagreb: Sveučilišna naklada Liber. Boban, Lj. (1965). Sporazum Cvetković-Maček. Beograd: Štamparsko preduzeće Kultura.

Brozović, D. (1997). Gramatičke značajke hrvatskog jezika, Jezik , 44 (4): 127-135.

Brozović, D. i Ivić, P. (1988). Jezik, srpskohrvatski/hrvatskosrpski, hrvatski ili srpski. Zagreb: Jugoslavenski leksikografski zavod »Miroslav Krleža«.

Duraković, N. (1993). Prokletstvo Muslimana. Sarajevo: Oslobođenje.

Đečević, M., Vuković-Ćalasan, D. i Knežević, S. (2017). Re-designation of Ethnic Muslims as Bosniaks in Montenegro: Local Specificities and Dynamics of This Process, East European Politics and Societies and Cultures, 31 (1): 137-157, doi: https:// doi.org/10.1177/0888325416678042

Filandra, ك̌. (1998). Bošnjačka politika u XX. stoljeću. Sarajevo: Sejtarija.

Hadžijahić, M. (1990). Od tradicije do identiteta (Geneza nacionalnog pitanja bosanskih muslimana). Zagreb: Islamska zajednica Zagreb.

Imamović, M. (1998). Historija Bošnjaka. Sarajevo: Preporod.

Isaković, A. (1990). O »nacionaliziranju« Muslimana: 101 godina afirmacije i negiranja nacionalnog identiteta Muslimana. Zagreb: Globus.

Ivanović, V. (2009). Hrvatska historijskodemografska situacija u Bosni i Hercegovini (1879. 1991.), http://chdr-ns.com/pdf/documents/beograd2009_vesna_ivanovic.pdf (15. 06. 2018.).

Jahić, Dž. (1991). Jezik bosanskih Muslimana. Sarajevo: Biblioteka Ključanin.

Kamberović, H. (2009). Bošnjaci 1968: politički kontekst priznanja nacionalnog identiteta, u: H. Kamberović (ur.). Rasprave o nacionalnom identitetu Bošnjaka. Sarajevo: Institut za istoriju, 59-81.

Kosančić, I. (1912). Novo-pazarski sandžak i njegov etnički problem. Beograd: Knjižara Gece Kona.

Kraljačić, T. (1987). Kalajev režim u Bosni i Hercegovini (1882. - 1903.). Sarajevo: Veselin Masleša.

Lisac, J. (1996). Hrvatski dijalekti i jezična povijest. Zagreb: Matica hrvatska.

Marić, F. (1996). Pregled pučanstva Bosne i Hercegovine između 1879. i 1995. godine. Zagreb: Katehetski salezijanski centar.

Matuz, J. (1992). Osmansko Carstvo. Zagreb: Školska knjiga. 
Mrđen, S. (2002). Narodnost u popisima. Promjenjiva i nestalna kategorija, Stanovništvo, 40 (1-4): 77-104.

Pačariz, S. (2016). The Migration of Bosniaks to Turkey from 1945 to 1974: The Case of Sandžak. Sarajevo: Center for Advanced Studies.

Pribićević, S. (1990). Diktatura kralja Aleksandra. Zagreb: Globus.

Purivatra, A. (1974). Jugoslavenska muslimanska organizacija u političkom životu Kraljevine Srba, Hrvata i Slovenaca. Sarajevo: Svjetlost.

Rudić, V. (1995). The Ethnic Structure of the Population in Montenegro, u: The Serbian Question in The Balkans. Belgrade: University of Belgrade - Faculty of Geography, https://www.rastko.rs /istorija/srbi-balkan/vrudic-montenegro.html (15. 06. 2018.).

Rudić, V. i Stepić, M. (1995). Ethnic Changes in the Raška Region, u: The Serbian Question in The Balkans. Belgrade: University of Belgrade - Faculty of Geography;, https:// www.rastko.rs/ istorija/srbi-balkan/vrudic-stepic-raska.html (15. 06. 2018.).

Šarkinović, H. (2004). Nacionalna, konfesionalna i jezička struktura stanovništva u Crnoj Gori po popisu iz 2003. godine, Almanah, 25-26: 197-210.

\section{IZVORI}

Definitioni rezultati popisa stanovništva od 31. januara 1921. god., Kraljevina Jugoslavija Opšta državna statistika, Sarajevo, 1932.

Nacionalni sastav stanovništva SFR Jugoslavije 1981. (podaci po naseljima i opštinama), knjiga I., Savezni zavod za statistiku, Beograd, 1991, http://publikacije.stat.gov.rs/G1981/ Pdf/G19814001.pdf (15. 06. 2018.).

Popis stanovništva, domaćinstava i stanova 2011. u Republici Srbiji. Stanovništvo: veroispovest, materinji jezik $i$ nacionalna pripadnost - Podaci po opštinama i gradovima, Republički zavod za statistiku, Beograd, 2013.

Popis stanovništva, domaćinstava i stanova u 1961. godini. Nacionalni sastav stanovništva FNR Jugoslavije (podaci po naseljima i opštinama), knjiga III., Savezni zavod za statistiku, Beograd, 1994, http://publikacije.stat.gov.rs/G1961/Pdf/ G19614001.pdf (15. 06. 2018.)

Popis stanovništva, domaćinstava i stanova u 2002. Stanovništvo: nacionalna ili etnička pripadnost - Podaci po naseljima, Republički zavod za statistiku, Beograd, 2003.

Popis stanovništva, domaćinstava i stanova u 2003. Stanovništvo: nacionalna ili etnička pripadnost - Podaci po naseljima i opštinama, Zavod za statistiku, Podgorica, 2004.

Popis stanovništva, domaćinstava i stanova u Crnoj Gori 2011. godine. Stanovništvo Crne Gore prema polu, tipu naselja, nacionalnoj, odnosno etničkoj pripadnosti, vjeroispovijesti i maternjem jeziku po opštinama u Crnoj Gori, Saopštenje br. 83, Zavod za statistiku Podgorica, 2011.

Popis stanovništva, domaćinstava, kućanstava i stanova u Bosni i Hercegovini 2013. Stanovništvo prema etničkoj / nacionalnoj pripadnosti - detaljna klasifikacija, Agencija za statistiku Bosne i Hercegovine, Sarajevo, 2016, www.popis.gov.ba/popis2013/doc/Knjiga2/HRV/K2_ T1_H.xlsx (15. 06. 2018.).

Popis stanovništva $i$ stanova 1971. Stanovništvo - etnička, prosvetna i ekonomska obeležja stanovništva i domaćinstava prema broju članova (rezultati po opštinama), knjiga VI., Savezni zavod za statistiku, Beograd, 1994, http://publikacije.stat.gov.rs/ G1974/Pdf/ G19744002.pdf (15. 06. 2018.). 
Prisutno stanovništvo po veroispovesti i maternjem jeziku po popisu od 31. marta 1931. godine Pregled po opštinama, Beograd, 1945, http://publikacije.stat.gov.rs/G1931/Pdf/G19314001. pdf (15. 06. 2018.).

Stalno stanovništvo po narodnosti po popisu od 15. marta 1948. godine [podaci su prezentirani po republikama, autonomnim pokrajinama te njihovim upravnim jedinicama $t j$. srezovima i gradovima, S. M.], Beograd, 1954, http://publikacije.stat.gov.rs/G1948/Pdf/ G19484001.pdf (15. 06. 1918.).

Stanouništvo Bosne i Hercegovine - narodnosni sastav po naseljima, Crkvenčić-Bojić, J. (ur.), Republika Hrvatska - Državni zavod za statistiku, Zagreb, 1995.

Stanovništvo prema nacionalnoj pripadnosti 1991. [podaci se odnose na Srbiju i Crnu Goru te na općine i naselja te dvije republike, S. M.], Republički zavod za statistiku, Beograd, http://publikacije.stat.gov.rs/G1991/Pdf/G19914021.pdf (15. 06. 2018.).

Ukupno stanovništvo po narodnosti - popis 1953. [podaci su prezentirani po republikama, autonomnim pokrajinama te njihovim upravnim jedinicama tj. srezovima $i$ gradovima, S. M.], Republički zavod za statistiku, Beograd, http://publikacije.stat. gov.rs/G1953/Pdf/G19534001.pdf (15. 06. 2018.). 


\section{Expression of National Affiliation in Population Censuses (1948-2011) among Sandžak Bosniaks}

\section{Saša Mrduljaš}

\section{SUMMARY}

Since the scope of the territory which can be brought into relation with the term Sandžak has varied during history, and considering that it does not form an administrative unit with the defined spatial frame, it is essential to define the areas belonging to Sandžak. For the duration of the Ottoman rule it was the easternmost part of the Eyalet of Bosnia. After the occupation of Bosnia and Herzegovina (hereinafter: $\mathrm{B} \& \mathrm{H})$ by Austria-Hungary, that part remained under Ottoman rule within the territory of Kosovo Vilayet. In terms of territory, it functioned as a kind of geopolitical wedge between Serbia and Montenegro. Considering that it occasionally represented a unique administrative unit, that part of the former Ottoman Bosnia was commonly referred to as the Sandžak of Novi Pazar. Nonetheless, during the final stage of Ottoman rule, it was divided into the Sandžaks of Pljevlja, Sjenica, Peć and Priština.

The whole area was divided in 1912, during the First Balkan War between Serbia and Montenegro. The division had been short-lived as it was followed by World War I (1914-1918) and by the occupation of the two countries. After the war, Montenegro was incorporated into the territory of Serbia, which later became part of the Kingdom of Serbs, Croats and Slovenes / Yugoslavia (1918-1941). Sandžak was again divided after World War II (1939-1945) due to federalization of socialist Yugoslavia. Approximately following the line of 1912, its northern part was annexed to Serbia, and southern to Montenegro.

The territory of Sandžak was finally defined upon administrative division of the Yugoslav republics into municipalities, carried out at the end of the 1950s. Its Serbian region became part of the municipalities of Priboj, Nova Varoš, Prijepolje, Sjenica, Novi Pazar and Tutin, and the Montenegrin one was incorporated into Pljevlja, Bijelo Polje, Ivangrad (which was its name until 1949, since 1992 it has been "Berane"), Rožaj (since the 2003 list; "Rožaje ") and Plav. Sandžak occupies 8.687 km², with its Serb part amounting to an area of $4.499 \mathrm{~km}^{2}(51.8 \%)$ and the Montenegrin to $4.188 \mathrm{~km}^{2}(48.2 \%)$. The number of municipalities we can consider as part of Sandžak has increased. While the municipality of Andrijevica was formed from the southern part of Berane municipality in 1990, Petnjica municipality was established from the northern part in 2012.

Mitrovica (Kosovo, Tito's) and its surroundings were also part of the Sandžak of Novi Pazar. After World War II it was integrated into Kosovo and has been perceived as its part. On the other hand, the modern notion of Sandžak includes the town of Plav in Montenegro, which did not use to be perceived as its part. Although Sandžak remains recognisable as a separate formation, it is essentially a historical perception maintained by the distinctiveness of its ethnic features. It is seen as a region inhabited by Bosniaks (predominantly in the east, towards Kosovo) as well as Serbs and Montenegrins (mostly in the west, towards B\&H).

This paper presents the data of all modern population censuses providing a more or less clear image of the ethnic features of Sandžak. The censuses included are those 
carried out between 1921 and 2011 within several countries, namely in the Kingdom of Serbs, Croats and Slovenes (SHS) (as of 1929; the Kingdom of Yugoslavia), socialist Yugoslavia, Federal Republic of Yugoslavia / the State Union of Serbia and Montenegro (1992-2003 / 2003-2006) and in independent Serbia and Montenegro (since 2006).

The indicators presented refer to the total population of Sandžak, providing basis for various analyses, comparisons and conclusions. The attached paper was focused on the Bosniak community. We have attempted to determine the extent to which the Sandžak Bosniaks have expressed their ethnicity or national affiliation in accordance with the Bosniaks in B\&H. The attempt was made both at the level of the entire Sandžak and of its Serbian and Montenegrin part. At the same time, the analysis conducted enabled the comparison of Bosniaks' census declaration in those two parts of Sandžak.

With regard to the objectives stated, the first two censuses, the ones from 1921 and 1931, are virtually unusable considering that they did not register ethnicity. As they contain data on religious affiliation and mother tongue, data on ethnicity may only be obtained indirectly, i.e. by combining the former two indicators. However, one should bear in mind that the data thus obtained only have approximate value, considering that the population might not have declared their ethnicity as such, had they had the opportunity in those years. Nevertheless, those censuses have a reference significance for the subsequent periods, so their indicators are also included in the paper.

The subjects of the analysis were primarily the results of the censuses conducted from 1948 until 2011, that is, the censuses allowing for an insight into the ethnic or national positioning of all the groups, including the Bosniaks. In the case of Bosniaks; in accordance with the political circumstances, the first three censuses conducted in socialist Yugoslavia were not aligned with the reality of their autonomy. However, they nevertheless offered opportunities to express their own identity, albeit indirectly. In 1971, in the context of political recognition of the national distinctiveness of Bosniaks, then known as "Muslims", new circumstances emerged in terms of quality, to be reflected in the subsequent two censuses. They have changed somewhat due to the replacement of the Muslim national name with the name "Bosniaks" in the early 1990s. This is also evidenced by the results of the censuses covering Sandžak after the disintegration of socialist Yugoslavia. The following conclusions may be drawn from the insights into census results as well as from their analysis and comparison.

Although the Communist government generally approached the Bosniaks as a separate ethnic entity, it took a long time to issue a political acknowledgement of the Bosniak national distinctiveness. This reality was already reflected in the first census carried out in 1948, in which the Bosniaks were given the opportunity to declare themselves as "undeclared Muslims" in order to demonstrate their own autonomy. In $\mathrm{B} \& \mathrm{H}$, almost $90 \%$ of Bosniaks identified themselves as such. In Sandžak, such declarations were rare and only occurred in its Serbian part, where Bosniaks mostly declared themselves as Serbs. In the Montenegrin part, they almost completely identified themselves as Montenegrins. Within the 1953 census, Bosniaks were provided an opportunity to declare themselves as "undeclared Yugoslavs", which was done by $95 \%$ of them in B\&H. In the Serbian part of Sandžak, the majority of Bosniaks also identified themselves as such, but a significant part of them declared themselves as Turks. Unlike the Serbian part of Sandžak, where Bosniaks decreasingly identi- 
fied themselves as Serbs, in the Montenegrin part, they continued to refer to themselves as Montenegrins. In that census, as well as in the subsequent ones, a smaller number of the Montenegrin Bosniaks identified themselves as Turks. In that and in the subsequent two censuses, expression of Turkish nationality was closely related to the then mass emigration of Sandžak Bosniaks to Turkey. Acceptance of Turkish national identity was supposed to facilitate the process of overcoming the constraints that have stood in the way of emigration from the homeland and immigration in the country specified.

In the 1961 census, Bosniaks were able to declare themselves as "Muslims in terms of ethnicity". In B\&H, almost the entire population of Bosniaks opted for that possibility, as well as the one that had been offered as the alternative possibility in the previous census ("undeclared Yugoslavs") In the Serbian part of Sandžak, the vast majority of Bosniaks declared themselves as "Muslims in terms of ethnicity", but again, a substantial number identified themselves as Turks. In the Montenegrin part; in 1961 the Bosniak population declared themselves as "Muslims in terms of ethnicity" and as Montenegrins in equal measure.

After the constitution of the nation of "Muslims" was politically accepted in the late 1960s, almost all Bosniaks from B\&H and Sandžak opted for that entry in the 1971 census. In the Serbian part, only a small number identified themselves as Turks. The 1981 and 1991 censuses are significant as they confirmed the 1971 rule, with a significant part of B\&H Bosniaks, together with Croats and Serbs, declaring themselves as "Yugoslavs". Such declaration was scarce in Sandžak.

As the Bosniaks accepted the replacement of their former national name in 1993, a new situation emerged, which was registered in the subsequent censuses. Within them, the reality of Bosniak nationality was accepted, but a possibility was left for declaring oneself as "Muslim" both in the territory of Serbia and Montenegro and of B\&H. Of the total number of declared Bosniaks and Muslims, the 2002 census counted close to $6 \%$ of Muslims in the Serbian part of Sandžak, while the 2003 census counted as much as $26 \%$ of them in Montenegro. It could be said that a part of the population declared in those censuses had not yet adequately perceived the significance of the changes relating to national affiliation, but would do so eventually. That situation was similar to the 1961 census, when a significant part of Bosniaks in B\&H did not declare themselves as "Muslims in terms of ethnicity" but as "undeclared Yugoslavs" in accordance with the previous census. In B\&H, that "anomaly" was bypassed already in the subsequent census. However, not in the case of Sandžak.

In the 2011 census, Muslims comprised $8 \%$ of the total number of declared Bosniaks and Muslims in the Serbian part of Sandžak, while there were almost $20 \%$ of them in the Montenegrin part. As opposed to that, in the first census that was held in B\&H after 1991, i.e. the 2013 census, Muslims comprised only $0.7 \%$ of the total number of declared Bosniaks and Muslims in that country. Additionally, it is indicative that in Montenegro and in the Montenegrin part of Sandžak, a significant part of Muslims identified themselves as Montenegrins both in 2003 and in 2011. In any case, the particular circumstances of Sandžak Bosniaks again had an impact on census expression of national affiliation. The differences between the Bosniaks / Muslims from its Serbian and Montenegrin parts are also noticed. The reason for this occurrence should be the subject of a special analysis.

KEY WORDS: Sandžak, Bosnia and Herzegovina, Bosniaks, Serbs, Montenegrins, population censuses 
